\title{
As convulsões europeias e os seus efeitos na América hispânica entre 1795 e 1815
}

European convulsions and its effects in Hispanic America between 1795 and 1815

Las convulsiones europeas y sus efectos en América hispánica entre 1795 y 1815

RémyHerrera

\section{Resumo}

Este artigo propõe uma série de reflexões acerca dos elos existentes entre os eventos que ocorreram de 1795 a 1815 simultaneamente na Europa e no vasto espaço que era então a América Hispânica. Durante o período considerado, os dois anos que podem ser vistos como pontos de viragem são 1807, quando da invasão da Espanha pelos exércitos franceses de Napoleão, e 1810, quando os movimentos de independência hispano-americanos iniciaram em caráter definitivo.

Palavras-chave: América Hispânica. Bolívar. Espanha. Europa. Napoleão.

\section{Considerações iniciais}

Este trabalho, que não é de um historiador nem pretende sê-lo, coloca em debate uma série de reflexões, ainda bastante iniciais, sobre os elos entre os acontecimentos que tiveram lugar de 1795 a 1815, simultaneamente na Europa e no imenso espaço que era, então, a América latina colonial. Se, no fim do período em estudo, (1815) puderam ser observadas, por todo o lado dentro desse conjunto, múltiplas tentativas de emancipação, mais ou menos resolvidas e organizadas, só uma parte do cone Sul, no Rio da Prata (Argentina e Paraguai), sem o Uruguai nem o Chile) definitiva e temporariamente, várias regiões de Nova-Granada (na Colôm-

\footnotetext{
Doutor em Economia e docente da Universidade Paris 1 Panthéon-Sorbonne. E-mail: herrera1@univ-paris1.fr
}

Recebido em 25/11/2016 - Aprovado em 20/02/2017 http://dx.doi.org/10.5335/hdtv.18n.1.6569 
bia atual) e Venezuela conseguiram desenvencilhar-se do jogo espanhol. Nos outros, os levantamentos foram esmagados em sangue quando eram vigorosos e em massa (mas indígenas, como na Nova Espanha da primeira metade dos anos 1810, o futuro México, na época, o território mais populoso do continente); neutralizados quando as elites locais preferiram assentar o seu poder sob a própria forma colonial política (como por exemplo, em Cuba); ou isolados, onde a Espanha concentrava as suas forças militares (principalmente no vice-reinado do Peru, até ao altiplano boliviano atual). O Brasil, recebendo a Sereníssima Casa de Bragança afastada de Lisboa pelas tropas de Junot, mas salva in extremis pela intervenção inglesa que transportou o regente D. João VI e a sua corte para a Baía, teve a sua trajetória própria, menos violenta, mas mantendo-se mais tempo que os outros assente na escravatura (RIBEIRO, 1995). ${ }^{1}$

Seria um erro metodológico, acrescido de preconceitos eurocêntricos, afirmar que os acontecimentos que agitaram na altura a América latina não obedeceram essencialmente aos movimentos das suas dinâmicas internas. Dinâmicas que estavam ligadas aos conflitos e às contradições que caracterizavam os seus indivíduos e grupo de indivíduos (chamados "classes", "raças", "nações", "povos", e quaisquer outra denominação (HERRERA, 2003; 2009), cujos processos entretecidos se originavam sempre nas singularidades de uma história, de uma geografia, de culturas e idiossincrasias, de instituições e de formações sociais que seria necessário examinar com cuidado e especificamente. A nossa ambição é muito mais limitada. Nas linhas que se seguem, esforçar-nos-emos apenas por identificar alguns dos efeitos produzidos neste Novo Mundo pelas convulsões maiores que, entre os anos de 1795 e 1815, transformaram o velho Continente - de que Inglaterra tomaria a liderança, e com ela a hegemonia sobre o sistema mundial capitalista, à saída do período; e também algumas influências externas marcantes que interagiram sobre as reviravoltas de alianças estratégicas operadas à escala mundial nesse momento.

Mas esses territórios latino-americanos diferenciavam-se nitidamente pela sua densidade de populações índia e negra um elemento chave para compreender os respectivos destinos dos movimentos independentistas locais - e estavam separados uns dos outros por obstáculos naturais, sem equivalência na Europa, que impediam consideravelmente as comunicações; os Andes, a Amazónia, Atacama ou até os llanos da bacia do Orenoco... Mas no curto intervalo histórico de que nos ocuparemos, o facto mais importante é que em todos esses territórios, os centros de poder, até aí artificialmente unificados pela coroa espanhola, a partir de 1808 , se cindiram numa variedade de juntas locais que se mantiveram (mais ou menos) fieis à metrópole; depois, de 1810 e através de guerras terríveis simultaneamente coloniais e civis, em entidades de comando autónomas convergindo para a emancipação política; e finalmente, depois de 1815 , em instancias de governo juridicamente independentes. Isso aconteceu porque na própria Espanha, o poder se desmoronara sob os golpes dos exércitos napoleônicos que se lançaram sobre todos os seus inimigos - e especialmente contra a Inglaterra. 
Também insistiremos aqui sobre as consequências que ocasionaram nas colônias hispano-americanas, primeiro o impulso, depois o refluxo das intervenções militares francesas na península ibérica a partir do Diretório e, mais decisivamente do Primeiro Império - intervenções que os grandes da Europa (e até os mais pequenos, como os Bourbons de Espanha e até a maior parte dos crioulos das Américas, entenderam melhor ou pior como a continuação extraterritorial de 1789, que ameaçava arrancar os privilégios da ordem antiga.

\section{Antes de 1795}

Nessas condições, o quadro mais geral da nossa análise só pode ser o das relações entre as duas potências dominantes da época, a Inglaterra e a França. Pois, quando em fevereiro de 1792, alguns dias depois da execução de Luís Capeto em Greve, a guerra recomeçou entre elas, esta fazia parte de quase um século de lutas. Esta "segunda guerra dos Cem Anos" tinha começado com o conflito de sucessão espanhola (1701-14), em que uma das implicações, seladas pelos tratados de Utrecht e de Rastant, teve de colocar um Bourbon no trono de Espanha (o duque de Anjou, que se tornara Felipe $\mathrm{V}$ sucedia ao último dos Habsburgos), mas igualmente o de impedir Luís XIV de pôr a mão nas colônias latino-americanas. Os Franceses tinham sido obrigados com efeito a abandonar sucessivamente a baía do Hudson, a Acadia, a Terra Nova e São Cristóvão, levados em 1713 pela Inglaterra (com a assinatura do tratado negreiro); depois os Países Baixos austríacos, cuja perda havia sido oficializada pelo tratado de Aix-la-Chapelle que punha fim à guerra da Sucessão da Áustria (1740-48); depois a maior parte do Canadá, cedido após a derrota da guerra dos Sete Anos (1756-63) - a mais grave e a mais decisiva - , e até às colônias da Índia administradas anteriormente por Dupleix.

Esses recuos parciais contínuos registados pela França marcavam a ascensão de uma Inglaterra que, no final das suas longas French Wars, ascendia sobre a sua rival. E essa tendência ia subir cada vez mais; nem mesmo depois da guerra americana da independência e da perda das Treze Colônias (1776-83) - que, aliás, desde a segunda metade do decênio de 1780 , se tornaram um dos maiores mercados externos das manufaturas inglesas. Com a sua agricultura modernizada, a sua indústria em plena revolução, o seu comércio projetado à conquista do mundo, a Inglaterra conseguia em casa escapar ao perigo radical, a ultrapassar as suas crises políticas e a aperfeiçoar uma monarquia constitucional que consolidava o poder da aristocracia (CHASSAIGNE, 2009). Graças à sua supremacia nos mares - e assim no ultramar - os Ingleses virados mais para o "outro lado" do que para o continente europeu, ${ }^{2}$ cujos portos em breve seriam fechados pelos blocos napoleônicos, começavam desde 1793 a atacar as possessões francesas das Antilhas.

Ao mesmo tempo nos Estados Unidos, apesar das simpatias francófonas de alguns, entre os quais Thomas Jefferson (embaixador em Paris até agosto de 1789), a inquietude ia dominando os ânimos à medida que a revolução se radicalizava em França. Os dois países estavam então ligados por um 
tratado de aliança militar assinado em 1778, depois da batalha de Saratoga e da decisão francesa de auxiliar os Insurgentes na sua luta contra a Inglaterra. Contudo, se o tratado de Paris de 1783) consagrava a ascensão dos Estados Unidos ao nível grande potência internacional, o presidente George Washington, consciente dos limites da sua força, envidou todos os esforços imagináveis para garantir a neutralidade do país. O seu sucessor, Alexander Hamilton, partidário do federalismo e apoiado pelos comerciantes da Nova Inglaterra, deu um passo em frente concluindo uma série de acordos, primeiro com a Grã-Bretanha (1794), depois com a Espanha (1795). Este último ia ser interpretado por muitos crioulos latino-americanos como um recuo preocupante da sua metrópole, ou seja, uma renúncia culpada, porque implicava da parte de Madrid a cessão dos direitos de navegação sobre o Mississipi e do entreposto de Nova Orleans, assim como uma mudança da fronteira da Flórida em proveito dos Estados Unidos. O distanciamento destes para com a França, perceptível depois da entrada em guerra da Convenção contra Londres, acentuava-se. Ele tornou-se inelutável em Fevereiro de 1794: a abolição da escravatura, proclamada por Robespierre e La Montagne que se dizia "terrorista", era inaceitável para os Estados Unidos, não apenas pelos plantadores do Sul que começavam a tirar grandes lucros do plantio do algodão, ainda maiores do que do tabaco, mas também por muitos capitalistas do Norte para quem a Declaração dos Direitos só dizia respeito a alguns homens, entre os quais não figuravam (Lincoln nasceu apenas em 1809) nem os Negros, nem os Índios -
Índios que perdiam as suas terras e as suas vidas, mas que normalmente podiam possuir escravos... (MELLON, 1988)

Claro, que depois de 1776, a declaração de independência dos Estados Unidos influenciara grandes frações das elites crioulas da América latina, que sonhava substituir os representantes da autoridade colonial peninsular, fazendo perdurar as estruturas socioeconómicas locais. Estas últimas eram extraordinariamente desiguais; muito mais do que em Espanha, embora divididas, hierarquizadas segundo critérios de segregação que se acumulavam: classe (proprietários/ não proprietários), origem (Espanhóis nascidos na metrópole/nas colônias ou crioulos) e sobretudo raça (Brancos/não Brancos, abrangendo os escravos negros africanos e os Ameríndios ultra explorados, os zambos que faziam parte deles, os mestiços também eles classificados segundo o grau de mestiçagem...). É que a ideia de emancipação propagada pelos "pais fundadores" de 1776 continuava a ser um reflexo fiel da sua própria formação social. Se, nas colônias inglesas da América do Norte, as classes dominantes tinham originariamente conseguido impor-se no centro de um modo de produção capitalista logo predominante e dotado de um Estado já subordinado à burguesia, ao contrário da América latina, mais antiga e manifestando ainda traços de feudalismo, muito cedo ligado aos mercados mundiais, uns e outros tinham um imperativo comum; o de preservar a todo o custo, sistematicamente, a supremacia dos colonos brancos de origem europeia perante todas as outras "comunidades". A independência dos Estados Unidos tinha ensinado aos crioulos lati- 
no-americanos a não olhar só para trás, para o esplendor de um passado de conquista; mas a tentar realizar as suas ambições, que estavam açaimadas pelo velho colonialismo espanhol e principalmente já pelo expansionismo territorial e o poder fenomenal do futuro do seu vizinho do Norte. ${ }^{3}$

Como já dissemos, profundas divisões atravessavam as sociedades do Sul. A sua demografia de conjunto, as suas composições étnicas, apresentavam fortes disparidades. E as desigualdades que dominavam a América latina - paradoxalmente menos racista do que a América anglo-saxónica, que não se mestiçou, ou muito pouco - estendiam-se aos mestiços e crioulos (mesmo quando esses podiam estabelecer a prova da sua "pureza de sangue", 4 através de discriminações múltiplas do status que sofriam. A palavra "crioulo" que se aplica aos brancos descendentes de Espanhóis nas colônias latino americanas ${ }^{5}$ era em si desprezível, já que transportada do vocabulário do tráfico e utilizado para a classificação de escravos: o crioulo designava inicialmente um negro nascido nas Américas, em oposição aos bozales, deportados de África, que tinham conhecido a liberdade antes de serem cativos. Sendo crioulos, as desigualdades eram realmente enormes perante a propriedade, principalmente a da terra, e em parte responsáveis pelas insuficiências permanentes nas mercadorias alimentares - daí decorrendo as repetidas fomes e epidemias - , refletiam-se até nos dados estatísticos das taxas de mortalidade (Calvo, 1994). Por consequência, os equilíbrios políticos estavam sempre ameaçados, as mentalidades feridas, as esperanças amputadas, os ódios exacerbados, as revoltas latentes. Num tal universo, preso em compartimentos sócio raciais estanques, o declínio secular da metrópole espanhola desde o esplendor dos Reis muito católicos e de Carlos V, que imaginaram reversível a partir de 1713 e de ressaltos de "despotismo esclarecido", nota-se um aumento do crioulismo.

Isso leva por vezes a revoltas muito grandes, como foi o caso dos Comuneros, em 1781, no vice-reinado da Nova Granada. Tudo começou quando o rei de Espanha Carlos III, desejoso de recuperar Gibraltar e a Florida, armou contra a Inglaterra (que já se encontrava em conflito nos Estados Unidos que não reconhecia) e enviou os seus agentes coletores a recolher nas colônias impostos destinados a financiar a guerra. Foi em El Socorro, entre a Madalena e a Cordilheira oriental, no departamento atual de Santander na Colômbia, que a recusa de respeitar os éditos reais - uma recusa passível da pena de morte - seria profundamente obstinada. Dirigida pelo chefe comunero Berbeo, que tinha às suas ordens cerca de 20 mil homens em armas, a revolta estendeu-se rapidamente e na direção dos quatro pontos cardeais, endurecendo e dando às suas reivindicações uma dimensão social e racial. Um dos líderes insurretos, Ambrósio Pisco fez-se proclamar cacique zipa do novo "reino chibcha" de Bogotá, e exigiu que os territórios espoliados aos ameríndios pelos espanhóis lhes fossem restituídos. A autoridade do vice-rei Flores foi desafiada até ao início do ano 1782 por José António Galán, que não aceitou capitular. Nos arredores da região de Santander, incitou os camponeses a ocupar as terras e libertou os escra- 
vos, principalmente os que trabalhavam em numerosas minas da região. Traído, preso, torturado, foi enforcado com os seus companheiros rebeldes em janeiro de 1782 - sendo os seus membros expostos como troféus de El Socorro até Charalá (sua cidade natal). Seus irmãos e amigos foram condenados ao chicote, depois deportados para o degredo espanhol da África.

Num movimento lento e ascendente, cresciam também ondas de rebeliões índias e negras, cada vez mais frequentes ao longo do século XVIII e do seguinte, cada vez mais angustiantes. Quando foi feito prisioneiro em 1761, depois da revolta yucateca de Cisteil, o que se tinha proclamado rei maia, a "serpente negra" Jacinto Uc de los Santos Kaan Ek, os chefes militares espanhóis acharam preferível desfazer o seu cadáver e esmagar os ossos - mas nessa poeira difundia-se cada vez mais o espírito da rebelião. Impossível também esquecer os traumatismos causados pelo Cuzco, à volta de San Domingo de Silos, pela "serpente luminosa" quechua Túpac Amaru II, José Gabriel Condorcanqui, que se dizia descender dos imperadores incas e até de Huayna Capac (pai de Atahualpa). Tinha começado por apresentar à Audiência de Lima uma petição em que exigia o fim do trabalho forçado para os índios. Era em 1776, e foi em vão. Quatro anos mais tarde eclodia a mais importante das insurreições da América do Sul. Ergueu ameríndios e mestiços e libertou os escravos - e as alfândegas. Condorcanqui, também chamado Quivicanqui e designado "Imperador da América", foi capturado em maio de 1781 na batalha de Checacupe, onde os insurretos enfrentaram os soldados (quase sempre ín- dios e cholos) enviados pelo vice-rei Agustin de Jauregui. Foi esquartejado e os seus com ele. Surgiu então, mais ao sul, Tupac Katari, para prolongar a luta. Também este teve o suplício do esquartejamento, e anunciou antes de morrer, em língua aimara: “É a mim que vão matar, mas os meus semelhantes em breve voltarão aos milhares!" E que dizer do medo pânico deixado pelos levantamentos negros de Coro, em 1795, ou um pouco mais tarde em Maracaibo, na costa ocidental da Venezuela? Isso acontecia em milhões de outras revoltas de escravos que explodiam por toda a parte na região: Jamaica, Cuba, Baía, São Vicente, Guiana, Porto Rico, Nova Espanha, Virgínia, Guadalupe, Curaçau, Granada, Santa Cruz, Tortola, para só lembrar algumas das que intervieram entre 1795 e 1815. Perante estes perigos, as elites crioulas latino-americanas apesar de tudo, necessitavam de Espanha.

Ali, como aliás em toda a parte as revoluções fazem sempre medo. Mais ainda quando não são brancas. Havia, perante os olhos dos crioulos o antecedente do Haiti, onde os pés descalços, como os sans-coulotte de Valmy e Jemmapes quase em simultâneo, tinham conquistado a liberdade. Mas desta vez tratava-se de negros, que tinham tomado os cânticos da revolta do hougan Dutty Boukman em Bois Caiman e colocado em ordem de batalha Toussaint Breda Louverture. Haiti, antigo São Domingo de Jean François e Biassou em agosto de 1791, onde colonos franceses outrora tentaram edificar uma sociedade que mais parecia um campo de concentração, patologicamente repressiva, incrivelmente disforme (465 mil escravos em 1789 , quase $90 \%$ da população). Um 
minúsculo pedaço de terra elevado a primeiro exportador de açúcar pela dilatação e pela sobre-exploração de uma mão-de-obra deportada de África, e que fornecia ao orçamento da França quase metade das suas receitas até à véspera da queda da Bastilha. Haiti onde haviam surgido as primeiras revoltas de escravos apenas dez anos antes da conquista da Espanhola (1503), bem antes das palenques de El Cobre no Oriente cubano, de Santa Marta sobre a Terra firme de Nova Granada e da Yanga afro-mexicana junto das canalhas de Vera Cruz. Haiti, que estupefato com a audácia da revolução francesa, que decidiu fazer a sua, com e contra a França, ou mais exatamente com alguns franceses, contra outros. Contrariamente aos Estados Unidos que antes dela tinham feito soar a hora da mudança nas Américas prolongando a escravatura dos Negros e tentando o extermínio dos Índios. O Haiti tinha aplicado à letra a mensagem lançada ao mundo pelo Incorruptível em fevereiro de 1794 e provando que todos os homens, não apenas alguns, podiam ser livres - pois deviam sê-lo na ilha, e segundo Toussaint, em toda a parte (CÉSAIRE, 1981). Esse ato pioneiro, essencialmente heroico, com o qual escrevia a sua história e oferecia o seu exemplo a todos os povos martirizados pelo capitalismo de acumulação primitiva, o Haiti pagou-o caro - e continua a pagá-lo ainda hoje. Não podemos, não devemos esquecer-nos disso.

Para todas as elites crioulas da América, do Sul ao Norte, a experiência haitiana foi - para além de uma catástrofe natural uma das piores coisas que podia ter acontecido. Outra que lhe estava intimamente liga- da era seguramente a propagação do sopro de 1789. Pois era essa revolução que tinha aberto a via da insurreição popular no Haiti, ainda antes de a escravidão aí ter sido abolida por direito. Essa abolição que aliás na época foi chamada "lei dos franceses", tanto por agitar o espectro do caos social (quando a reação a ela se referia, do México ao Alto Peru), tanto por deixar entrever a esperança de uma emancipação (quando dela falavam os escravos cimarrones, de Cuba à Venezuela, ou de Pernambuco, ou Minas Gerais). Claro, que houve exceções, homens extraordinários, como por exemplo, o jovem Francisco de Miranda y Rodriguez (RUMAZO GONZALEZ, 2006), que serviu no exército do Norte de Dumouriez até à frente da Flandres, ou do gigante político que foi Simon da Santíssima Trindade Bolivar y Palacios, que viveu nas Luzes. Bolívar que declarou: “Todos os povos que escolheram unir-se pela liberdade acabaram por derrotar os seus tiranos". Ou: "A soberania dos povos é a única autoridade legítima das nações" (PEREIRA, 2005 e ARGOTTI CÓRCEGA, 2012). Exceções, que em alguns casos, de uma forma ou de outra e cada um à sua maneira aderiram aos ideais revolucionários.

O neogranadino António Narino, que encontrou Miranda em Paris e mais tarde ajudou Bolívar, foi preso por ter traduzido em espanhol a Declaração dos Direitos do Homem e do Cidadão, e lançado na masmorra, em Cadiz. Um dos grandes intelectuais quiteños de Santa Cruz e Espejo, filho de um índio e de uma mulata descendente de escravos, foi igualmente preso por ideias julgadas subversivas, e apoio às revoltas indígenas que haviam decorrido ao longo da 
cordilheira andina até Quito, nas terras dos comuneros. Antes de empunhar armas e dirigir o primeiro movimento de insurreição neoespanhol Miguel Hidalgo e Costilla também tinha lido os autores da "Ilustração" - foi reitor da Universidade de Valladolid (atual Morelia no México) e fez imprimir em Guadalajara, com Ignacio Aldama, um dos primeiros jornais insurretos, "O Despertar Americano". Foi esse mesmo Hidalgo que lançou um dia às suas tropas: "Americanos, quebremos os laços de ignorância a que nos amarraram há muito!" Poderíamos mesmo citar aqui o controverso José Gaspar Rodriguez de Francia, discípulo muito excêntrico de 1789, que presidiu aos destinos do Paraguai libertado. Esse país, herdeiro dos velhos "comunismos" índio e cristão, foi um dos primeiros a conseguir a sua independência nas Américas, depois de ter recuado e a Espanha e os alvos dominadores argentinos (como Manuel Belgrano na Mesopotamia); sem dúvida também entre os mais avançados nos planos econômico e social de todo o continente em meados do século XIX, antes de ser martirizado pela fúria destrutiva dos exércitos da Tripla Aliança, auxiliados pela Inglaterra vitoriana - sob o pretexto de defender a livre-troca. ${ }^{6}$

Primeiro a Revolução francesa, depois o Império - por mais fundamentais que fossem as rupturas de uma à outra - teriam exercido uma influência sobre algumas elites cultivadas do Novo Mundo espanhol, esta fase inicial da emancipação latino-americana, que vai de 1810 a 1815, não pode ser tomada pelo produto do espírito conquistado pela nova ideologia dos direitos do homem. Repetimos: geralmente os crioulos, aí incluindo os movimentos independentistas, viram essencialmente na França um perigo, o maior de todos: o de um caos que engolira ali o Antigo Regime e que arriscava destruir neles o seu sistema de dominação. Num contexto colonial onde a hierarquia de raças ampliava as ligações de classe, o receio suscitado pela ameaça de um levantamento de massas não brancas, o ódio contra a ideia de igualdade, muitas vezes a recusa de ver limitar os poderes da Igreja, ganhavam sobre qualquer sentimento. Torna-se um fato incontornável: o curso que a história tomou na França para além de exercer uma influência ideológica; produz acontecimentos que acabaram por tornar passíveis, primeiro o isolamento, depois o afastamento, e finalmente a marcha lenta e difícil para a independência das colônias latinas. Esta última é assim uma implicação direta do tumulto militar - e consequentemente o enorme vazio político - que os ataques das tropas francesas iam provocar na península ibérica.

\section{De 1795 a 1807}

A irrupção francesa teve etapas. Em 1795, a Espanha, enfraquecida, atormentada pela mediocridade da família real, foi vencida pelo Diretório. Teve de assinar o tratado de Bale pelo qual se viu obrigada a lançar-se de novo na guerra contra a Inglaterra. Sem dúvida era o inimigo de sempre, mas o jogo de alianças complicara-se recentemente ao inverter a linha de longo termo da diplomacia espanhola. Depois de incendiar o "braseiro francês" a Convenção proclamou em 1793 a sua vontade de "trazer a liberdade e a igualdade em Espanha" e de "fazer desa- 
parecer os Pirineus"' (PÉREZ, 1996), Londres tornara-se a aliada obrigatória. A ocupação do País Basco e da Catalunha pelas forças convencionais, desde 1794, tinha, no entanto, forçado Madrid a retirar-se da Primeira Coligação em 1795 e, depois do tratado de Ildefonso (1796), a renovar com Paris uma aliança tradicional - mas contrariada e numa posição submissa. Para a Espanha, a consequência imediata da retomada do conflito com a Inglaterra foi uma derrota militar: a sua frota, sendo a terceira do mundo e reforçada há alguns decênios (sem ter conseguido conquistar a aura e eficácia da Invencível Armada) foi derrotada ao largo do Algarve, na batalha de São Vicente em fevereiro 1797) - onde surgiam já, sob as ordens do almirante Jarvis, dois futuros heróis nacionais, Horácio Nelson e Cuthbert Collingwood. A Espanha deixava assim aí uma colônia de localização estratégica, Trinidad, situada ao norte da embocadura do Orenoco: logo a seguir perdeu Santo Domingo.

$\mathrm{O}$ mesmo aconteceu à marinha de um outro aliado recente da França, a República batava, vencida em Camperdown nove meses mais tarde. Os Países Baixos abandonaram muito à Inglaterra (Ceilão, Malaca, Sumatra, Bornéu...) - como a própria França, depois da ruptura brutal da paz de Amiens em 1803 (Saint-Pierre-et-Miquelon, Santa Lúcia, Tobago, Martinica, Guiana, Senegal, Mascarenhas e Seychelles, Java e até Van Diemn's Land) Mas o que acontecia a Espanha era realmente preocupante: a guer$\mathrm{ra}$, em que os Ingleses reinavam sobre o mar, cortou de fato as comunicações entre a península e o Novo Mundo (LAVALLÉ, 2004). Assim, desde o início, os territórios da Amé- rica latina encontraram-se isolados e pela força das coisas, por assim dizer, autónomos. Desde 1797, Madrid decidiu terminar (temporariamente, mas segundo se provou em pouco tempo, definitivamente) o monopólio do comércio colonial com as Américas, e autorizava as ligações com os "neutros" - ou seja, concretamente, as trocas diretas com os Estados Unidos (PORTES, 2010). Quase na mesma altura, após o lamentável "caso Talleyrand" o Congresso de Filadélfia cancelava o tratado de aliança militar e comercial que os ligava à França há vinte anos. Para os comerciantes da costa leste dos Estados Unidos, afastados dos mercados das ilhas caribenhas inglesas depois da declaração da independência, a gratidão para com a solidariedade francesa de outrora tocava os seus limites.

Nessa luta intensa a que se entregavam Ingleses e Franceses, no meio de todas as outras, alguns sinais iniciais deixavam prever as dificuldades intransponíveis que os segundos teriam de enfrentar para vencer os primeiros desde o tempo da ascensão de Bonaparte. Fora especialmente o caso da derrota naval da França em Aboukir, a 1 de agosto de 1798, que fez acabar com os planos de controlo da rota do Oriente, logo alguns dias após a vitória das Pirâmides. Mas foi definitivamente a humilhação sofrida em Trafalgar, a 21 de outubro de 1805, que constituiu o momento determinante do desenrolar dos acontecimentos. Com uma manobra inovadora, a frota do almirante Nelson passou na perpendicular as linhas francesas dispostas em círculo (BAYNTON-WILLIAMS, 2008) enviando para o fundo simultaneamente com os navios inimigos, os seus projetos 
de invasão de Inglaterra - dez anos após a expedição gorada à Irlanda. Apesar desses revezes marítimos. O Império corria de vitória em vitória no continente, até dominar a maior parte da Europa, depois da derrota na Áustria e na Rússia, mal coordenadas em Austerlitz. Mas, a Inglaterra, decididamente, continuava a avançar os seus piões à escala global, instalando pontos de apoio estratégicos do Báltico à África do Sul, das Antilhas a Oceania, iniciando já, principalmente sob o impulso dos irmãos Wesley, a conquista da Índia profunda, para dela fazer em breve o coração do seu vasto império colonial (CHASSAIGNE, 2009). A inferioridade marítima da França, que Napoleão tentara reduzir, com grandes planos de conquistas longínquas que se tornavam cada vez mais irrealistas, mesmo irrisórios: São Domingos, Brasil, Senegal, sempre o Egito, a Índia claro

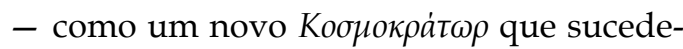
ria à antiga Macedónia - para já não falar, aos antípodas, da Terra australis... Saído do continente europeu, onde o seu voluntarismo rapidamente se tornou loucura, o Imperador dos Franceses não tinha decididamente os meios para realizar as suas ambições.

Movido por uma hostilidade tornada em obsessão (porque justificada) para com o adversário principal, Londres, de onde vinham "todos os males" - , Napoleão que por todo o lado fazia dobrar os soberanos europeus, soube mostrar-se polido com os Estados Unidos. Sem dúvida demasiado polido. Concedeu em 1800, que a convenção de Mortefontaine os desligasse finalmente dos compromissos militares com a França compromissos que nunca mais teriam para com ninguém antes de se terem tornado a hegemonia do mundo. Atiçou o conflito entre eles e a Inglaterra, que impedia as suas trocas comerciais, lhes tomava os navios, e contratava até "desertores" estadunidenses... até ao Ato de Embargo, e, principalmente, a guerra de 1812 . Houve também em 1803, o presente oferecido a Jefferson, que só queria Nova Orleans e conseguiu por 15 milhões de dólares os 2,1 milhões de quilómetros quadrados da Luisiana Francesa, graças aos quais os Estados Unidos duplicaram a sua superfície, para lá do Mississipi. Tendo, por baixo do pano, uma garantia de não intervenção da França contra os seus interesses - garantia que englobava todo o sul do país. Mas não no Haiti. Aí, Napoleão, usou uma violência extraordinária contra o último sopro da revolução que ele próprio acabava de dominar em França. Esse facto é por vezes esquecido ou silenciado: no ano de 1804, a sagração em Notre Dame (parece que sob o olhar de um jovem venezuelano durante algum tempo parisiense, prometido à eternidade) igualmente o do prestígio máximo do Grande Exército - o melhor que a França tivera em toda a sua história - , 1804 tornava-se um marco, para o Haiti, desta vez em terra e não no mar. Recusando as correntes, antigos escravos, mestiços, Jacobinos e outros (até Polacos!) infligiram aos soldados de Napoleão as suas primeiras derrotas 20 anos antes da última batalha contra as forças do Duque de Wellington e da Sétima Coligação.

O povo haitiano teve de bater-se, sozinho, ou quase, e às vezes contra si próprio (CHIN et al., 2004). - já que os Estados Unidos recusaram reconhecer-lhe a sua jovem independência, a 1 de janeiro de 1804 e lhe 
colocaram um embargo. Com outros, Dessalines (nascido em África antes de ser escravo, depois nomeado general por Toussaint, que lhe nascera escravo na plantação de Breda, perto do Cap-Français, na costa setentrional), conduziu a segunda parte da revolta lançando a ofensiva contra Rochambeau - após a norte de Leclerc, em 1802 - e a invasão da parte oriental da ilha, então ocupada por Ferrand. É inútil falar aqui da atrocidade dos combates e lutas como em tantos outros locais das Américas e da Europa nessa altura. Ou de voltarmos à questão do regresso da escravatura às colônias, em que Napoleão se atolava. Dizia-se que o Imperador hesitava em restabelece-la e que estava mal influenciado por este ou por aquele. Mas se a oscilação que teve foi somente a da agulha numa balança que calculava os lucros e as perdas, nada de admirar quando um dos coveiros da Comuna de Paris reconheceu:

Uma parte considerável da nobreza francesa já espoliada dos seus bens em França pela Revolução, era ao mesmo tempo colona em São Domingos e espoliada das ricas mansões que outrora possuíam nessa ilha. Não lhes queriam devolver os bens em França, que se haviam tornado nacionais, mas podiam entregar-lhes as suas fábricas de açúcar, os seus cafezais em São Domingos (...) e era uma compensação que parecia poder satisfazê-los...(CÉSAIRE, 1981)

Napoleão compreendeu tarde as implicações dos acontecimentos no Haiti, se dermos crédito aos seus últimos remorsos, confiados em Santa Helena, onde terá reconhecido que um dos seus erros mais graves cometidos durante os 13 anos e meio de reinado - tal como Alexandre - seria (não a Rússia, nem a guerra exagerada, mas sim a prisão de Toussaint (CASANOVA, 2008). O outro foi evidentemente a invasão de Espanha. ${ }^{7}$ Aí chegaremos. Antes disso, vejamos o que se passava então na América latina, que começava a agitar-se.

Ao Sul, no vice-reinado do Rio da Prata, as coisas iam apressar-se. Jacques de Liniers, um emigrante francês, vindo de uma família da pequena nobreza, ao serviço de Espanha para melhorar uma carreira militar bloqueada pelos golpes orçamentais de Turgot, encabeçava a resistência às tentativas sucessivas dos Ingleses, cheios de glória pela conquista da colônia holandesa do Cabo, para se apoderar de Buenos Aires e de Montevideu (1806-07). Habituado às proezas contra a Inglaterra, aquele que lá longe era conhecido como Santiago de Liniers y Bremond (daí o nome de reconquistador rechaçava com êxito as tropas de Pophan e Whitelocke. O mérito do contra-ataque pertencia aos crioulos platenenses (entre os quais Domingo Cristobal French entre outros) mais do que aos Espanhóis. Delineavam-se já os contornos de um sentimento nacional. Após a retirada inglesa, de Liniers foi nomeado vice-rei do Rio da Prata. O imperador, entre Iena e Eylau, ocupado em pôr ordem no bloco, apenas recebeu a notícia com interesse. Enviou imediatamente um emissário, o marques de Sassenay, mas a aventura deste acabou mal, já que foi feito prisioneiro e o barco ancorado em Cadiz - mas com mais sorte que a epopeia de Liniers, que lhe acabou com a vida, vencido pelos jacobinos portenhos da Revolução de Maio, em cabeça de Tigre, perto de Córdoba, diante de um pelotão de execução. Em Londres, já se sabia há muito tempo que as mercadorias podiam 
entrar de contrabando e que uma derrota militar não impedia que os capitais se instalassem - embora o Brasil, país aliado onde os Ingleses penetravam sem hostilidade, estivesse muito perto. Em Paris começavam a entender que a história de todos esses territórios longínquos era bastante mais complexa que antes e muito paradoxal. Pois se as colônias latino-americanas não ousavam enfrentar a metrópole espanhola elas não iam submeter-se à Inglaterra, mas ponto crucial, estavam ainda menos dispostas a tornar-se francesas.

No norte do continente desta vez, e um pouco mais tarde, em 1806, uma ofensiva dirigida contra uma outra colônia espanhola, a Capitania Geral da Venezuela, tinha-se também gorado. A de Miranda, sonhando com a independência e parte dos Estados Unidos, que não se importavam, sob o olhar dos Ingleses, complacentes, ou mais exatamente que nada tinham a perder. Esta experiência precoce, até prematura, enfrentou todas as dificuldades: o despreparo das forças insurreccionais, a intervenção de tropas francesas (enviadas de Guadalupe) para apoiar a Espanha e, principalmente, a hostilidade dos crioulos. O local do desembarque, Coro, um dos portos donde seguiam para a metrópole as riquezas dos Índios, fora mal escolhido. Os seus habitantes, ainda sob o choque das grandes revoltas de escravos de 1796, mantiveram-se fieis a Deus e ao rei até mais tarde que os outros. Convém acrescentar a isso os rios de propaganda lançados contra a pessoa de Miranda, acusado de ser "plebeu" (rico, mas filho de emigrante canário, não pertencendo portanto à oligarquia crioula), "revolucionário" embora há muito tivesse acalmado os seus ideais com conservadorismo) e "pró-francês" (não tinha combatido em Valmy, depois de se ter aproximado dos Girondinos?), "herético" (e contaminado pelo ateísmo para uns, apoiado pelos protestantes para outros)... (PÉREZ, 1996) Em Julho de 1807, na costa extremo-oriental de Cuba, os Franceses (em nome dos quais um parente dos Lafitte que reinavam sobre o "reino da Baratania" como eles meio corsário meio pirata, um certo You) ajudavam os Espanhóis a defender Baracoa dos assaltos de Tait e da Royal Navy. Napoleão tinha, portanto, razões para se queixar de Madrid: ela travava uma guerra sem convicção contra a Inglaterra - o, que, afinal se podia entender -; mas principalmente, parecia já não ligar às colônias.

Aparentemente. Pois, por um estranho fenômeno que logo se notou, e que vamos examinar, esses territórios da América latina continuaram unidos à sua metrópole, pelo menos durante algum tempo. Entregues a si próprios, não se desligaram logo de Madrid. Os Franceses, o próprio Imperador, tinham subestimado muito as capacidades da resistência espanhola. Havia circunstâncias atenuantes para este erro de julgamento. Depois de vários decénios e mais ainda depois da sucessão ao trono, de Filipe V, neto de Luís XIV, não se tornara este país um satélite de Paris? Já há séculos mesmo não avançara inexoravelmente para o declínio? É verdade que o seu "renascimento" cultural recente e a sua aceitação das "Luzes" - traduzida nas Américas pelas "Reformas Bourbônicas" prometidas ao longo do século XVIII, que de resto só tinham adeptos nas esferas crioulas (VILLAR, 2011) - podiam deixar crer que os partidários da mudança eram numerosos na península. É preciso ver também para lá dos desgostos (até conjugais) do fraco Charles (Carlos) IV, para entender toda uma sociedade e as suas classes. Pois se a Espanha, antes de perder o seu rei, já não tinha verdadeira- 
mente Estado, se o seu poder político era apenas ficção - quando o Godoy velhaco e incompetente, "príncipe da paz", imitava os Floriblanca (que tinha já afastado do posto de secretário de Estado) e grandes cobradores dos tempos antigos -, abaixo da corte, havia um povo, cujas forças vivas eram fortes e decididas.

Povo de miséria, de contradições, herdeiro de uma história de lutas locais, comunais, regionais, enraizando-se, após a invasão de um Tarik Ibn Ziyãd, nos seis séculos de reconquista empreendida contra os Mouros até finais das guerras de Granada que derrotaram o reino de Boabdil - e precedendo as outras três de conquista americana. É preciso levar também em conta essa experiência, de um passado complexo e rude, que um Marx, ${ }^{8}$ ele mesmo, entendeu bem melhor que a maioria dos seus contemporâneos europeus, para abarcar o drama que aguardava os Franceses. Mas o génio de Marx, não soube avaliar o de Bolívar. Talvez este último lhe lembrasse menos Napoleão o grande - do que o pequeno "Bandiguet" que acabava de desancar no seu 18 Brumário de Luís Bonaparte. Sem dúvida, na nossa opinião, ainda que esta ideia não tenha sido verdadeiramente explorada, porque Marx pensava, na época em que escreveu sobre Simón Bolívar, que em Espanha a revolução exigia previamente um longo processo de centralização monárquica, que ao contrário da França, por exemplo, fez falta na historia latina - próxima de sistemas de domínio do tipo otomano ou "de regimes asiáticos" -, e contra o qual se levantou o Libertador, partidário simultaneamente da independência e da república... Isso merece estudos mais aprofundados. Mas avancemos.

\section{De 1807 a 1810}

O ponto de viragem é conhecido: é o outono de 1807, a entrada das tropas napoleônicas em Espanha. Mas a origem de todo este caso data de um ano antes, quase dia por dia, quando Napoleão impunha pelo decreto de Berlim (26 de novembro 1806), o bloco continental respondendo ao bloco marítimo dos Ingleses contra as costas da Mancha e do mar do Norte. A interdição que foi feita ao Império francês e a todos os seus aliados de comerciar com as Ilhas Britânicas foi ulteriormente reforçada pelos decretos de Fontainebleau e Milão (outubro-dezembro de 1807). É esta linha estratégica, fundamental, que motivou a anexação dos Estados pontifícios, depois da Holanda e das cidades hanseáticas, antes de constituir mais tarde um dos maiores motivos do agravamento dos desacordos com a Rússia - o Czar Alexandre I tentando contornar no mar Báltico as decisões ordenadas pelo imperador. Apesar da grande oposição, até da França - o que obrigou em breve a conceder licenças para alguns portos -, esse dispositivo tinha demonstrado certa eficácia. Contribuiu para mergulhar na crise, várias vezes, uma Inglaterra isolada na Europa e por assim dizer sempre obrigada a voltar-se para os revoltosos do Novo Mundo - embora "o ouro de Pitt" o Jovem, o que foi Chanceler do Tesouro, financiasse em larga medida os Coligados. Era necessário, portanto, fazer respeitar os blocos, estritamente, e por todo o lado. Isso, na península ibérica, onde o contrabando ia muito bem, mas onde subsistia um aliado indefectível de Londres: Portugal. 
Este último perturbava abertamente a aplicação; e era uma das causas da guerra entre ele e a Espanha em 1801, a das "Laranjas" - que teve consequências contraditórias na Europa (amputação do território português) e na América do Sul (extensão do Rio Grande do Sul em detrimento das colônias espanholas). Entendemos assim porque até 1807, além dos seus insucessos a por o pé na América latina (principalmente em Buenos Aires, porto florescente donde saiam tantas riquezas de mineração e agricultura), os Ingleses tinham sabido pacientemente instrumentalizar o curso dos acontecimentos nesse continente auxiliando no caso de alguns independentistas (exemplo, Miranda) contra uma Espanha aliada de Paris, para abrir o torno do bloco que os asfixiava. Esses apoios de circunstância - tão pouco filantrópicos como os interesses que iam levá-los a proibir o comércio transatlântico - modificaram-se bruscamente em 1807.

No fim desse ano, com efeito, desenhavam-se cada vez mais claramente, as vantagens que Napoleão poderia retirar de uma intervenção na península ibérica. Claro, que em Portugal, onde o motivo era evidente, Junot foi prontamente lançado contra Lisboa. Mas também contra Espanha, pois que com esta dominada, o imperador contava arrancar aos Bourbons ao mesmo tempo os territórios americanos, embora longínquos, até secundários, mas de não deitar fora na luta agora global contra o inimigo inglês. À sua volta as opiniões chocavam-se (MASSIN, 1965): enquanto Talleyrand tentava aproveitar a ocasião da ridícula confusão em que se debatia então a família real espanhola para invadir o país e arrancar-lhe o poder. Fou- ché, persuadido da inutilidade dos riscos inerentes a uma tal operação, e talvez consciente do perigo que previa, tentou dissuadir Napoleão a fim de preservar a paz, pelo menos temporariamente. $\mathrm{O}$ imperador decidiu; e fê-lo seguindo a opinião do primeiro. Decidido a domar a Espanha, forçou o príncipe das Astúrias, imbuído de autoridade sob a sua "proteção" a dar a sua aprovação para fazer transitar para o território espanhol os soldados franceses em marcha para Portugal. A 13 de novembro, um corpo de 25 mil homens, comandado por Dupont, foi enviado para Espanha para apoiar o avanço de Junot, que entrou em Portugal a 19 e tomou Lisboa a 30, após a batalha de Abrantes. No princípio de janeiro de 1808, tropas suplementares, sob as ordens de Moncey, seguidas por Dupont, tropas suplementares, sob as ordens de Moncey, seguiam as de Dupont, que se aproximava de Valladolid sem encontrar grande resistência. À altura da sua reputação, Carlos IV levou bem um mês ou seja o tempo que os franceses levaram para ocupar inteiramente Portugal - antes de resolver-se a enviar uma carta ao imperador, pedindo-lhe para lhe dar uma explicação para a presença de tantos soldados franceses no solo do seu reino. A 20 de fevereiro, Murat, afastado das suas ambições sobre a Polônia, foi nomeado comandante em chefe do exército de Espanha.

Os acontecimentos precipitaram-se. Um plano, ousado, provavelmente elaborado meses antes aquando das negociações Talleyrand-Kourakine preparatórias do tratado de Tilsit (julho de 1807), que deixava à Rússia os territórios europeus do império otomano e o campo livre na Ásia, firmado 
no tratado de Fontainebleau (outubro de 1807), foi proposto ao governo espanhol: Carlos IV conseguia Portugal, contra todos os territórios espanhóis situados a norte do Ebro que voltavam para a França. Como única resposta o rei fugiu para Sevilha, pronto para seguir para as Américas - como fizera três meses antes D. João VI, sempre regente, mas instalado no Rio de Janeiro, com a nata da aristocracia portuguesa, e logo a seguir, "pela graça de Deus e a aclamação unânime do povo" Rei do Brasil transformado em reino... Surgiram depois as jornadas insurreccionais de Aranjuez (18-19 março), levando à destituição e prisão de Godoy, depois a sua libertação contra a abdicação de Carlos IV a favor do príncipe das Astúrias. A 24 de março de 1808, a chegada do novo eleito Ferdinand (Fernando) VII numa capital madrilena em delírio seguida em apenas algumas horas da instalação do verdadeiro soberano, o lugar-tenente Murat nos salões do Escorial. No dia seguinte, o antigo soberano Carlos IV foi obrigado a rever a sua decisão e a depor a coroa nas mãos de um Napoleão impaciente por substituir um Bourbon (pai ou filho) por um Bonaparte. Mas qual? Luís declinara a oferta para manter a Holanda. Cerome imitava-o e mantinha a Vestefália. Lucien mantinha-se hostil e nunca foi mais do que um príncipe de Canino (pela vontade do papa Pio VII, muito controlado). Só restava um dos membros da sua irmandade, José então rei de Nápoles.

Para o imperador estava fora de questão reconhecer Ferdinand. A Toscana que acabava de ser administrativamente cortada estava livre. A 20 de abril, em Baiona, o general Napoleão ofereceu ao tonto e mau
Fernando trocar a coroa de Espanha pela da Etrúria. O filho domado, o pai e o resto da família - com Godoy, favorito de Carlos IV (e preferido de Maria Luísa de Bourbon - Parma) - foram imediatamente chamados a França. O contexto, lembremos, era já o desencadeamento da repressão francesa em Madrid, onde Murat, secundado por Grouchy, enviava os seus mamelucos para os combates de rua contra os patriotas amotinados (2 e 3 de maio). A 5, por tratado, Carlos IV abandonou a Napoleão os seus direitos ao trono de Espanha (e às Américas) e, no paroxismo de um conflito mundial onde rivalizavam insultos de moços de fretes e ricochetes vaudevilescos, ${ }^{9}$ obrigaram Ferdinand a faze-lo. O primeiro seguido dos seus e das suas extensões, sem esquecer o Príncipe da Paz e o duque de Alcudia y de Sueca, foram transferidos em residência vigiada para Compiegne: o segundo, para o pequeno Chambord de Valençay, propriedade do ex-bispo d'Autun, camareiro-mor e recente príncipe de Benevent (na Campânia, lugar de nascimento do pai do seu hospedeiro...), Charles-Maurice Talleyrand-Perigord. O trono de Espanha ficava assim para o único Bonaparte que não se opusera a Napoleão: o irmão mais novo, José. Assim, enquanto no início de junho uma assembleia favorável ao novo Rei José I reuniu-se em Baiona a fim de aprovar a nova Constituição - quase progressista - mas quase toda a Espanha se levantava. Parte das regiões não inteiramente submetidas pelos Franceses, a Andaluzia, as Astúrias, a Galiza, o que hoje se chama em Espanha a "guerra da independência" tinha começado. Logo, desde o início do mês de maio de 1808 e as cargas francesas às Portas do Sol. 
Nesse país que sofria ainda as sentenças da Inquisição, erguia-se já a cruzada contra "o Anticristo corso" e o anticlericalismo francês vindo da Revolução. Gente do alto clero, como o arcebispo de Granada ou o coadjutor de Sevilha, e também regimentos de fradinhos fanáticos, desempenharam um papel no movimento contra o usurpador José, "herético", "luterano", "franco-maçom" (MASSIN, 1965). Houve purgas contra os "afrancesados" e os liberais partidários do governo da França. Desde 22 de Maio, não tinha o bom Pio VII qualificado o sistema francês de "protetor de todas as seitas e de todos os cultos, sem excluir a sua religião judia, o inimigo implacável de Jesus Cristo e afirmado que era "o mais injurioso, o mais oposto à religião católica? Amém! Mas o levantamento espanhol representava mais do que isso; era mais do que esta obscura reação religiosa, arcaica, fechada a qualquer ideia de razão e progresso. O facto, inegável, é que uma maioria do clero e das elites, embora visceralmente xenófobas, se lançaram aos pés do ocupante estrangeiro, quando as classes populares nas suas largas componentes entraram na luta armada contra o invasor, a partir de 2 de maio. Era essencialmente uma luta pela liberdade, ou melhor pelas liberdades (mais comunais, defendidas ferozmente desde as revoltas antigas contra todo o poderio de um Carlos V e do Sacro Império romano germânico). Era simultaneamente uma luta de libertação nacional. Pois esta abstração de "nação", incarnada nos clamores dos sapateiros de Kellermann e afirmada no "Terror" montanhês quando os Prussianos estavam apenas a 30 léguas de Paris, reaparecia em Madrid, como um espectro, quase três lustres mais tarde. Nesse conflito, o que a Espanha trouxe à arte da guerra, é a invenção da guerrilha, de que os Franceses descobriram a eficácia nas suas vitórias, anunciando as suas derrotas para obter sucesso. Isso não impediu, contudo, alguns partidários de empregar os seus tesouros de inventividade na crueza para com os soldados napoleôicos que conseguiam capturar... (DAMAMME, 1998).

Em toda a Espanha constituíram-se juntas, tomando - para melhor o defender - o poder confiscado ao soberano pelos Franceses. Nesses casos, com algumas exceções, foram homens novos que encabeçaram a resistência; mesmo que frequentemente as massas se voltassem para as notabilidades locais (ou pelo menos para aqueles que não tinham traído a pátria) a fim de os representar. A 8 de junho de 1808, a junta de Sevilha, declarava guerra à França, que contava já com quase 120 mil homens em solo espanhol, até Córdoba. Menos de duas semanas mais tarde, juntas provinciais (a de Oviedo entre outras) tinham já enviado os seus emissários através do mar Cantábrico, para obter de Londres o apoio do ministro dos Negócios Estrangeiros britânico, George Cunning. Desde o início de junho, o que restava da frota francesa três anos depois de Trafalgar estava logicamente arrasada e mais uma vez ao largo de Cadiz, pelos assaltos combinados de navios ingleses e espanhóis que obrigaram o contra-almirante de Rosily-Mesros a render-se. Mas, contra toda a lógica, os acontecimentos em terra firme não se passavam como previsto. Como de resto no continente, os combates travados pelas tropas francesas eram inumeráveis; 
mas, aí, as vitórias já não eram totais, os seus homens muitas vezes recuavam perante o inimigo. Ou capitularam. Foi o que aconteceu no coração da Andaluzia, a 22 de julho de 1808.

Dupont de l'Estang, que teve de rearmar-se aos pés da Serra Morena, em Andujar, no Guadalquivir, foi humilhado em Bailen pelas tropas do general madrileno Castanos Aragorri, comandante do Suisse Reding de Biberegg, do marquês valão de Coupigny e o irlandês Félix Jones. Dupont ordenou a 17 mil franceses (aos seus e aos de Vedel) que depusessem as armas - o que lhe valeu receber no seu regresso a degradação e as mesmas masmorras que Toussaint Louverture no Forte de Joux (antes da sua reabilitação sob a Restauração). A derrota de Bailen, a primeira infligida na Europa aos exércitos do império, teve uma repercussão profunda. Da Prússia à Áustria, começava a constar que nesta Espanha rebelde já não eram as tropas regulares, mas sim os partidários, modestos guerrilheiros, que se dizia parecerem munidos apenas de bestas da Idade Média, ou apenas com a camisa, nas cordilheiras béticas à Serra da Guadarrama ou ao Maestrazgo, que enfrentavam sem medo as forças imperiais consideradas invencíveis (LENTZ, 2004).

O belo Murat, futuro Joaquim-Napoleão, que se preparava para recuperar a coroa de Nápoles (à falta da de Portugal, recusada e Espanha, invejada) deixou o comando do exército na pior altura. Desamparado, e apenas dez dias depois de ter chegado a Madrid, José teve de deixar a capital (30 de julho), investido pelos Espanhóis a 13 de agosto. Estes rechaçavam os Franceses em várias frentes. Em Portugal, também não iam melhor: depois de aí ter desembarcado a 1 de agosto à frente de 13 mil homens (sem contar os exércitos portugueses) Wellesley empurrou Junot para o interior, levando-o mesmo até à Roliça (17 de agosto), no Vimeiro, (a 21) e a Sintra (30). Ao mesmo tempo, para emendar a mão e pôr ordem na península ibérica, Napoleão mandou para lá quase metade das tropas do Grande Exército estacionado então na Prússia (o exército do Reno) depois de ter impedido com o czar um eventual avanço austríaco feito nas costas dos Franceses (o Romanov, claro, que nada fez mesmo depois do recontro de Erfurt). Nos últimos dias de outubro de 1808, Napoleão, que tinha mandado atravessar o norte do Ebro para preparar a contraofensiva, pôs-se em marcha para Espanha. No princípio de novembro, chegou a Vitoria de Alava basca onde tudo estava pronto para executar o seu plano - tudo ou quase, já que Ney e Lefebvre, corajosos, mas pouco disciplinados, continuavam a marchar, um para Rioja depois de Logroño, o outro para a Cantábria e Santander.

Mais uma vez, a estratégia do imperador funcionou. O general Castanos recuava no centro, depois da vitória de Soult e de Bessieres em Burgos; o andaluz Blake y Joyes foi vencido em Espinosa por Lefebvre e Victor; o aragonês Palafox e Melzi recuava sob a pressão combinada de Ney e Lannes (em meados de novembro). Este último, que o imperador reservava para os ataques mais difíceis, saía vitorioso da batalha de Tudela (23). Alguns dias mais tarde, após um avanço de corrida, e as explorações de lanceiros poloneses no desfiladeiro de Somosierra, 
Napoleão retomou Madrid (4 de dezembro de 1808). Como é estranho este povo espanhol que continuava a resistir quando aqueles homens lhe retiravam com um decreto os seus direitos senhoriais, da Inquisição e das suas "instituições horrendas" - o momento em que outros franceses, farinha do mesmo saco, tentavam acabar com a escravatura e os trabalhos forçados no grande ducado de Berg e noutros lados. Mas não era contra essas conquistas e seus princípios que os Espanhóis se levantavam; era contra o facto de estarem reduzidos na sua pátria à submissão, ou de já não terem a ilusão de serem donos de si próprios. De resto, o levantamento espanhol inquietava pelas suas ambiguidades todos os aristocratas da Europa, embora cheios de ódio por aquele que eles continuavam a chamar "Bonaparte"; só aplaudido quando os nobres e todos os seus lacaios conseguiam o lucro que podiam retirar, e as suas vinganças. Eis porque a análise de classes, completada por um estudo do problema nacional, nos vai esclarecer melhor do que qualquer outra.

Mas não é esse o nosso fim. Voltemos antes ao que se passava na América latina. Se podemos fiar-nos embora com prudência no testemunho de um Fouché, ministro da Polícia, o imperador ter-lhe-ia confiado, no decorrer de uma entrevista que teria tido lugar antes da intervenção na península ibérica:

Resolvi unir a Espanha aos destinos da França. Quero assim aproveitar a ocasião única que o destino me apresenta de regenerar a Espanha, de libertá-la da Inglaterra e de a unir ao meu sistema (...) Pensar que o sol nunca se põe na imensa herança de Carlos V e que terei o império dos dois mundos (FOUCHÉ, 1993).
No começo do mês de maio de 1808 , já com Madrid "pacificada", Napoleão pedira a Murat que preparasse navios. José Napoleão - o próprio Napoleão se necessário, ou seja, se os espanhóis não se mostrassem mais dóceis devia reinar em Espanha e todas as suas colônias. O imperador decidira cedo colocar os seus peões: Vicente de Emparan, como governador de Caracas, Gregorio da Cuesta no México... Como em muitos lugares Napoleão utilizava legiões de agentes especiais (por vezes secretos) para conseguir informações e obter apoios, da Nova Espanha até ao cone Sul. Lembremos o desaire de Sasseney, chegado a Buenos Aires em plena rebelião pró Fernando VII para encontrar aí o impetuoso Liniers (monarquista, naturalizado espanhol mas nascido em Niort e sempre demasiado francês!) pouco tempo, em julho de 1809, substituído por um vice-rei mais bem disposto no que respeitava à Espanha e aos interesses do comércio crioulo.

As missões mudaram bruscamente no México ou Cuba ou na Venezuela. Em Caracas, o espaço de tempo em que os fernandistas estiveram por cima chegou para fazer cair na armadilha inglesa o infortunado Lamanou, enviado de Caiena por Victor Hugues - esse último que desde 1809, era atacado pelos portugueses, apoiados pelos navios corsários britânicos de um certo Yeo (Sir James Lucas, a não confundir com o flibusteiro francês Dominique You que já encontramos anteriormente) Até à longínqua capitania geral das Filipinas que permanecia realista, e leal para com as juntas - principalmente de Sevilha, de Cadiz em segundo lugar. As ordens do imperador, é certo, não eram aplicadas em todo o lado igualmente 
com o mesmo zelo que um Touzard, então cônsul em Nova Orleans e partidário total da independência do México (que na época estava para lá do Texas) - mas cujos esforços não conseguiram impedir o esmagamento dos primeiros movimentos de emancipação conduzidos por Hidalgo. Aliás era a brandura que prevalecia. - o caso de um Serurier, embaixador de França em Washington, que arrastava as negociações com os independentistas de Caracas, temporizava com os de Cartagena...(BENOT, 2006). Desconfiados de uns, tergiversações burocráticas (já) de outros consumiram o tempo tão precioso dos insurrectos em busca de apoios externos, e acompanharam na queda as rebeliões precoces da América latina. A começar pela da Primeira República de Veneza. Desde as expedições de Santo Domingo e seus desastres, julgava-se que o imperador já não tinha força para converter as suas palavras em atos.

Perante esta situação extremamente delicada, de repetida incapacidade a fazer reconhecer a autoridade de José I nas colônias latino-americanas, a partir dos anos 1810, Napoleão ia mudar radicalmente a sua estratégia para com elas: como não conseguia apossar-se de nenhuma e como os realistas lhe resistiam, apoiaria assim todas as lutas para a independência. E, ao fazê-lo, por um efeito de simetria invertida, essa escolha poderia acentuar ao máximo as novas contradições que a Inglaterra devia enfrentar. Asfixiados pelo bloco continental, vitalmente obrigados a manter abertos os territórios (ou mercados) da América latina, com os quais as trocas comerciais tinham sido muito recentemente "liberadas" e evitavam a maçada do contrabando, como os Ingleses, que se haviam tornado aliados de uma Espanha quase totalmente ocupada pelas tropas napoleônicas, poderia continuar a apoiar as várias rebeliões independentes que amadureciam? Embora a junta suprema central, alcandorada na borda do rochedo em Cadiz mas representando para lá dos seus conflitos a instituição provisória da resistência espanhola, gritava ao mundo não querer largar o império colonial do Reino de Espanha (PÉREZ, 1996).

\section{De 1810 a 1815}

Os Ingleses, que sabiam que estavam sozinhos, olhavam para uma bússola: a guerra total, global contra a França. Se contavam também com alguns estrategistas militares de talento, no plano político, a francofonia de um Canning (nos Negócios Estrangeiros) ou de um Castlereagh (como secretário de Estado da Guerra e das Colônias), por exemplo, servia para cauterizar os arranhões das feridas intragovernamentais. Em Londres, estavam persuadidos da impossibilidade de uma perenização do domínio imperial francês. Tratava-se no fundo, de um choque de sistemas. Aliás, para lá das figuras individuais da história, Napoleão não teria conseguido vencer perante as baixezas abissais dos dois Bourbons de Espanha e a alienação mental (oficialmente declarada) das duas outras cabeças coroadas que os cuidados do dr. Willis e das suas camisas de forças não conseguiam curar nem um nem outro (em Inglaterra, Jorge III de Hannover, e a de Maria a Louca em Portugal). Pacientemente e militarmente, os Ingleses desafiavam a França entre 1793 e o congresso de Viena de 1815 (exceto alguns meses de 1802-03, após a paz de Amiens). 
Claro que o fizeram nas colônias, mas acabaram por fazer o mesmo no continente europeu; no preciso local, em que pela primeira vez, os soldados do imperador tinham sido obrigados a parar: na península ibérica. Apesar das reticências iniciais de Londres, devidas sobretudo ao custo financeiro que esse conflito implicava, a Espanha bem depressa deixou de ser uma frente secundária aos olhos dos Ingleses, para se converter no teatro maior de operações - especialmente entre a derrota austríaca e a campanha da Rússia. Foi em solo ibérico que ia destacar-se o futuro vencedor de Waterloo, Arthur Wellesley, duque de Wellington, levando à glória homens políticos que o mereciam menos do que ele. Em outubro de 1810, A Inglaterra rompia as negociações sobre as trocas de prisioneiros com a França. Esta queixava-se, com razão, do destino horrível reservado aos seus (muitos dos vencidos em Bailén tinham perecido em cativeiro, nos batelões minados pela febre de Cadiz ou na ilhota deserta de Cabrera); esta reiterava as suas exigências de ver as Cortes reconhecidas como única entidade representativa, e Fernando VII reinstalado no trono. Afastadas todas as perspectivas de paz, seria uma longa luta; na verdade uma luta de morte (CHASSAIGNE, 2009).

Depois da batalha de Talavera (julho de 1809), 80 mil homens comandados por Wellington concentravam-se para defender Lisboa, ou evacuar Portugal, se a ofensiva francesa a isso os tivesse levado. O plano inglês era de resistir o mais que pudessem, aguardar que Londres permitisse enviar reforços, e depois lançar o contra-ataque. Wellington ordenou a fortificação de Torres Vedras nuns quarenta de quilômetros (ou "linhas de Torres") O que se fez desde meados de fevereiro de 1810, graças à requisição em massa de trabalhadores portugueses forçados (e com o acordo benévolo da junta de Lisboa e do regente carioca).

O objetivo procurado era o de tentar impor uma guerra de posição aos oficiais franceses que mais se destacassem. Já Massena, à frente do exército de Portugal, avançava sobre Ciudad Rodrigo, Almeida... Mas quando Portugal estava a ponto de ser retomado, do lado francês, a discórdia entre os chefes militares era cada vez mais visível. Em Paris, Berthier sabia: Massena enfrentava oposições internas, principalmente da parte de Ney, Reyner e Junot, que comandavam os três corpos do exército. Os desacordos aumentavam, explicando a quase derrota do Buçaco que permitiu ao inimigo abrigar-se. Quarenta mil franceses detinham-se diante de Lisboa, cujos acessos estavam controlados por 70 mil anglo-portugueses entrincheirados.

Isolado, Massena recuou em meados de fevereiro de 1811. Aguardara apoios que não vieram embora o tivesse exigido. Sob censuras, uns e outros tinham desculpas; na verdade todos estavam ocupados e Soult, um dos heróis de Austerlitz que comandava agora o exército de Espanha do Sul, era o primeiro. A decisão de Massena de dispensar Ney, por recusar obedecer às suas ordens, escondia mal as suas responsabilidades pessoais. O duque de Rivoli, outrora, "filho querido da vitória" perdera o brilho, tendo até de ser nomeado príncipe de Essling. Não evitara a derrota de Reyner no Sabugal juntando-se-lhe? Não deixara em maio de 1811, em Fontes de Oñoro, de dar o golpe de misericórdia a um Wellington vencido, mas lúcido até na derrota e conseguindo salvar o seu exército de uma perda, que nesse momento teria sido fatal para os Ingleses? Dir-se-ia que seriam necessários os reforços de Bassière e do exército de Espanha do Norte, os quais mais uma vez não chegaram. Ou que o erro era 
de um imperador ocupado com outras coisas e pouco concentrado na organização de combates a mais de mil quilómetros de Paris (MASSIN, 1965). Mas a verdade era que o resultado estava ali: os soldados franceses retiravam-se completamente de Portugal no princípio do mês de abril de 1811. Massena foi substituído por Marmont.

Mas havia também dificuldades em Espanha. Desde 1810, a situação parecia ter-se estabilizado, devido a uma série de vitórias. José Napoleão reinava em Madrid no centro, coberto ao Sul pelo exército do Midi, chefiado por Soult e colocado sob as ordens diretas do imperador e ao norte pelas autoridades militares (Catalunha, Aragão, Navarra, Biscaia). Sevilha caíra também. No princípio do ano de 1811, a maior parte de Espanha estava ocupada pelos franceses - exceto a Galiza, Valencia, Tarragona e claro, Cadiz sempre cercada por Victor. Mas, por toda a parte a guerrilha atacava-os, sempre rechaçada mas sempre de volta, e era sem dúvida feroz... Lembrava algumas vezes as antigas técnicas de combate utilizadas pelos berberes, senhores das montanhas, quando se viraram contra os Árabes no tempo da conquista moura do Andaluz (LÉVI-PROVENÇAL, 1932).

Para as forças napoleônicas, a "pacificação” do país parecia não ter fim. Quando as tropas francesas saíram de Portugal Wellington colocou as suas em marcha para enfrentar Soult. Badajoz, conquistada por este último em março de 1811, foi cercada em abril, obrigando o francês a deixar Sevilha. No mês seguinte, sob o comando de Beresford, teve de subir mais para o Norte. As vitórias de Suchet, da tomada de Tarragona à armadilha de Valencia (em setembro) dificilmente obliteravam as perdas sofridas. Sem falar dos problemas financeiros; o imperador obrigara as tropas a suprir as suas necessidades, ou a apre- sentar as despesas dos exércitos ao rei (ou seja, José, cujas dividas acumuladas ultrapassavam o orçamento de França). Pobre José cuja autoridade madrilena era incessantemente desafiada pela junta insurrecional espanhola e pela Inglaterra, contestada pelas ordens militares francesas e dependente de modo inquietante de um irmãozinho arrogante que partia à conquista do universo... No que constituía ainda as colônias espanholas da América latina, e afastadas quaisquer tentativas iniciais, dispersadas e infrutíferas as vagas de independência só aumentaram verdadeiramente a partir do princípio do ano de 1810 . Mais precisamente depois de terem chegado ao outro lado do Atlântico as notícias (largamente disseminadas pelos Ingleses) da ocupação quase integral da Espanha pelos exércitos napoleônicos, do ataque destes últimos à Andaluzia, e da fuga precipitada da junta de Sevilha pelas fortificações de Cadiz. Foi nessa altura, que corresponde à viragem da posição do imperador quanto ao futuro desses territórios (prontos no fim do ano 1810) que as explosões se produziram. Tudo vacilou em 1810 e os representantes do reino de Espanha iam ser vencidos quase em toda a parte. No Sul, por um lado, foram obrigados a demitir-se: em Buenos Aires, nos levantamentos da Revolução de Maio; no Chile, com a formação de um congresso "autônomo". No Norte, foram depostos: o vice-rei em Nova Granada, onde fora proclamada a criação das Províncias unidas; na Venezuela, a capitania geral, pela junta de Caracas, desde o mês de abril de 1810. Manifestações de descontentamento surgiram ainda, do golfo de Darien até ao istmo de Tehuantepec. Só o Peru conseguia impor a continuidade da ordem do monarca espanhol. Mas mesmo aí onde a autoridade da metrópole parecia recuar, as elites crioulas latino-americanas estavam desunidas. As de Coro e 
de Maracaibo, por exemplo, realistas, recusaram reconhecer os poderes da junta caraquenha. Quito, que não pudera enviar representante a Espanha, não se associou mais aos movimentos que agitavam então Bogotá e Cartagena das Índias. As divisões eram mesmo mais marcadas no Rio da Prata, onde as forças centrífugas se exerciam para afastar de Buenos Aires tanto o Paraguai, sob o impulso de Rodrigues de Francia como, sob o de Jose Gervasio Artigas, a banda oriental (ou o futuro Uruguai, que nascia quase ao mesmo tempo que a Bélgica, pela vontade inglesa de separar e enfraquecer potencias regionais e rivais.

Mas foi no Vice-reinado de Nova Espanha que esses acontecimentos se tornaram mais radicais. A seguir ao Grito de Dolores (setembro de 1810) a luta pela independência do México foi lançada por Miguel Hidalgo y Costilla e pôs em movimento as massas indígenas herdeiras de Cuautémoc e dos que tinham defendido até ao fim Tenochtitlan. Padre crioulo, apaixonado pela justiça, colocou-se ao lado dos humildes e comandou um exército de 50 mil homens contra as elites peninsulares e crioulas que, entretanto, se uniram contra o levantamento popular. Nas regiões que conseguiu libertar tentou-se algo muito semelhante a uma reforma agrária quase um século antes da palavra de ordem "terra e liberdade" dos revolucionários Emiliano Zapata e Jose Doroteo Arango Pancho Villa. Um decreto de dezembro de 1810 aboliu a escravatura. Traído, aprisionado, condenado à morte, Hidalgo foi passado pelas armas em Chihuahua a 30 de junho de 1811, depois decapitado. Colocado num cofre de ferro preso a Alhondiga de Granaditas (mercado de cereais) de Guanajuato, a cabeça daquele a quem chamam o Pai da Pátria, foi exposta, com as dos seus companheiros Juan Aldama, Ignacio Jose de Allende, Jose Mariano Jimenez e seus mineiros que se juntaram a ele, durante dez anos - ou seja até ao dia da independência do país. No intervalo, um dos discípulos de Fidalgo, Morelos y Pavon, também ele padre, relançara a luta dos Mexicanos pela justiça social.

Mais ao Norte, a situação estava muito confusa, num Texas apanhado no outono das aspirações independentistas do Sul e as ideias anexionistas do Norte. Os Estados Unidos finalmente abocanharam-no ao seu vizinho, enquanto perto de metade do seu território, recuava para lá do Rio Bravo na época da guerra de 1845, que iria mergulhar o México no caos, e preparar a intervenção francesa de 1862. Desde meados de dezembro de 1810, Napoleão informara o embaixador da França em Washington que não se oporia a que os Floridos se tornassem possessão americana, acrescentando que desejava no geral tudo o que pudesse favorecer a independência da América espanhola (BENOT, 2006). Assim o imperador fazia compreender claramente aos Estados Unidos, na véspera da guerra que ia de novo (durante três anos desta vez) colocá-los em posições opostas contra a sua antiga colônia cuja guerra foi igualmente o momento de uma nova expansão territorial dos Estados Unidos que já não pretendiam fundar o comércio sobre pretensões exclusivas e que concordavam com a independência de toda a nação "desde que não ficasse sob influência da Inglaterra". É verdade que, pelo seu lado, a França napoleônica, que recuava agora na península ibérica e que se preparava para se lançar nos espaços sem fim da Rússia (DAMAMME, 2009), já não tinha qualquer colônia no fim de 1811. O importante era o continente europeu, onde a ilusão de domínio definitivo ainda se fazia sentir em Paris: a anexação da Catalunha, não marcava a expansão territorial máxima do Primeiro Império, cujos departamen- 
tos se estendiam como ramos tentaculares, para lá das fronteiras naturais da França, primeiro para o Leste e o monte Tonerre, empurrando fortemente a Confederação helvética (o monte Terrible e Simplon), mas principalmente em direção da Itália, até Roma, confiscada após a recusa do papa em fazer aplicar nas suas terras o bloqueio, levando todo o Norte até aos Países Baixos? Os poderes do gigante imperial não se estendiam até à embocadura do Elba e às do Ebro? Não era isso recompensa suficiente pela perda de terras longínquas? (BUTEL, 2002).

Nos territórios da América latina, a agitação tornava-se cada vez maior. Na Venezuela, onde dois desembarques tinham já sido tentados em 1806 por Francisco Miranda - o primeiro malogrou-se e conduziu-o a Trinidad, o segundo viu os crioulos da Vela de Coro levantar-se contra ele e forçá-lo a voltar para Inglaterra - as lutas pela libertação recomeçaram. Tinham tido os seus pioneiros com Miranda, como José Maria Espana, executado em 1799. A sua dinâmica levou a junta de Caracas a proclamar a independência, a 5 de julho de 1811, e a fazer adoptar, por um congresso eleito por sufrágio de censo, uma Nova Constituição (dezembro). Dizem que a insurreição englobava as Províncias Unidas de Nova Granada, com as quais fora logo estabelecida a ligação, graças a Bolívar. No fim do ano de 1811, a província de Leon y Granada (Nicarágua) insurgiu-se, antes que a rebelião ganhasse El Salvador, depois, um pouco mais tarde Tegucigalpa (Honduras). Foi aí que surgiu o cura José Matias Delgado. Em setembro de 1811, Artigas venceu a batalha de Las Piedras, seguido do cerco de Montevideu. Na Nova Espanha a guerra popular recomeçara após a execução de Hidalgo, cuja bandeira fora erguida por José Maria Morelos y Pavon. Este último, mestiço, nascido em Valla- dolid (atual Morelia, entre o México e Guadalajara), antigo camponês e arrieiro, depois padre, tinha sido instruído por Don Hidalgo y Costilla, antes de liderar o movimento de emancipação indígena até à sua morte. $\mathrm{O}$ incêndio correu as fronteiras do Texas até às da Prata. Mas, rapidamente, as tropas lealistas espanholas conseguiram extingui-las, ou julgaram tê-las extinguido. Durante algum tempo, conseguiram controlar a situação - salvo no Paraguai, onde a declaração de independência de Maio de 1811 não voltou a ser posta em causa, nem pela península nem por Buenos Aires (JESÚS PÉREZ CRUZ, 2011).

O exército do Norte das Províncias Unidas do Rio da Prata não conseguiu invadir o Alto Peru e foi batido em Huaquipar por José Manuel Goyeneche y Barreda, que contra-atacou. As tropas espanholas foram detidas na sua progressão para o Sul pelas de Manuel Belgrano em Tucuman em setembro de 1812), depois de novo em Salta fevereiro 1813) e já não puderam avançar após a derrota de Ayohuma perante os realistas (novembro). Nessas lutas pela independência, a importância dos levantamentos indígenas merece ser destacada. Foi nessa época que Juana Azurduy de Padilla, pelo seu papel ativo junto do exército de Belgrano, se tornou uma heroína do povo boliviano. E a própria Argentina, hoje tão "branca", que se considera "povo europeu transplantado" (RIBEIRO, 1995) — pode contar com combatentes negros (escravos) e índios (originários dos povos indígenas desde Tawantinsuyu à Patagónia), que na sua maioria foram abandonados à fome e à doença após a vitória. Livre da sua Capitania Geral, o Chile sofreu o ataque das forças do vice-rei do Peru José Fernando de Abascal, chegadas por mar em Fevereiro de 1813, mas que não passaram para lá do Chillian. Mais ao Norte, a reconquista espanhola, que fora lançada 
a partir do mês de Março de 1812 pelo capitão espanhol Domingo Monteverde, a sua artilharia e os 16 mil homens desembarcados da Metrópole, terminou em Junho. Depois da capitulação de San Nateo em Julho, a Primeira Republica estava perdida. Era preciso aguardar até ao Verão seguinte para que os independentistas retomassem a ofensiva.

Entretanto, Miranda fora preso, em La Guaira, enviado para morrer como tantos outros em Cadiz (BOHÓRQUEZ, 2008). Cadiz, paradoxal, no seu rochedo, preso por um fio à terra andaluza, que continuava a falar em nome das Índias; cercada sem jamais cair, minúsculo recanto de resistência a Napoleão antes da nova reconquista do país. Cadiz na época muito provavelmente a cidade mais progressista de todo o reino, em que as Luzes não haviam sido muito "tamisadas", mas onde acabaram os seus dias, entre a Isla de Leon e o arsenal da Carraca em San Fernando, alguns dos primeiros independentistas hispano-americanos. Paradoxal também nesse ano de 1812, no decorrer do qual uma "Constituição liberal" que mergulhava as suas raízes profundamente num passado de lutas permanentes pelas liberdades das comunas e das regiões da península, e assim de tal modo avançados no seu tempo (pois, num sentido) "revolucionário", iluminando de tal modo e tão repentinamente a noite negra espanhola como o grande cometa que então passou, no preciso instante em que uma das repressões mais brutais se abatia sobre os insurrectos independentistas da América latina. Poderemos então ser progressistas em casa e continuar colonialistas no ultramar?

Tantas contradições nesse local, entretecidas, tantos conflitos imbricados nesse tempo. Nesse fim de ano de 1812, as tropas napoleônicas guardavam os bastiões em Espanha, mas não avançavam. Marmont tinha perdido os Arapiles e 14 mil dos seus homens (em julho). De um extremo da Europa, onde se afundava inexoravelmente, passava a outra, um abismo na realidade, onde iria ser engolida até a Guarda Imperial. Perecia nos dois extremos do continente que já havia dominado; nesses dois países considerados os mais arcaicos, os mais abafados pela religiosidade, instituições de outra era. Mas onde existiam as maiores possibilidades de resolver as contradições internas do capitalismo em que penetravam com uma lentidão infinita, graças ao acesso à terra procurado pela colonização, ultramarina para Espanha, para Ocidente, terrestre para a Rússia, em direção ao Oriente. Dois países onde, ao mesmo tempo sob a opressão político-religiosa, pululavam já forças regeneradoras que levaram mais tarde, sobre os traços de poeira deixados por 1789 , outras revoluções, que aguardavam o seu reacender. ${ }^{10}$ Por agora, é certo, que a campanha da Rússia tinha sido retardada pelos usuários parisienses - a hostilidade de fracções da burguesia para com Napoleão que lhes levava um Estado para reinar era perceptível em França - que tardava a conceder crédito e retardava cada vez mais até ao Inverno, ou seja a catástrofe final. A sorte parecia lançada para o imperador apanhado entre as chamas de Moscou e os gelos terríveis da retirada russa. A Sexta Coligação estava formada, reunindo em volta da Inglaterra, a Rússia, a Áustria, a Prússia, os Estados alemãs e tantos outros. Castlereagh e Wellesley, Alexandre Pavlovitch Romanov e o marechal Koutousov, o príncipe de Metternich-Winneburg e o seu fogoso "Marschall Vorwärts" Blücher, o König Friedrich Wilhelm III von Preußen e um cortejo de reizinhos germânicos, aos quais era preciso juntar as progenituras Bourbon, espanhola e a Casa 
de Bragança portuguesa, um papa (Pio VII), um Carlos numero XIV feliz por ter ganho a lotaria sueca (Bernardotte), Talleyrand e Fouché conspirando nas suas costas (e um contra o outro) sem esquecer ainda o conde de Provença (exilado em Buckingham), era um mundo.

A 21 de junho de 1813, na véspera do fim do armistício temporário entre a Rússia e a Prússia, os Franceses de Jourdan foram esmagados em Vittoria, perto de Pamplona, deixando aí 5 mil mortos ou feridos e quase 20 mil prisioneiros. Os Pireneus começavam ali, a Noroeste. Em outubro, mesmo quando os exércitos napoleônicos perdiam ainda 30 mil à Völkerschlacht de Leipzig, as tropas do duque de Wellington irrompiam em Bidassoa, depois em Nivelle e Nive, e penetravam em território francês. Era a primeira entrada do inimigo no "santuário nacional". Sem perder tempo em discussões com o seu primogênito, embora preocupado, Napoleão decidiu o fim dos assuntos de Espanha. Desde o Verão que esta estava perdida no campo militar provavelmente antes depois da partida forçada do imperador quando se anunciou o rearmamento austríaco (meados de janeiro de 1809). Foi exposto um plano a seu "primo" - a verdade era que por aliança desde a união de Napoleão, a 2 de abril de 1810 nas Tulherias, com a arquiduquesa de Áustria, Marie-Louise de Habsbourg-Lorraine, sobrinha da malograda Marie Antoinette; sabendo que do seu lado, pelos pais (também primos) Fernando descendia de Luís XIV... Fernando ia ser libertado e autorizado a reinar em Espanha. $\mathrm{O}$ acordo satisfazia a Inglaterra, já que levava a um cessar fogo e à retirada dos Franceses da Península que ameaçavam envolver as forças de Wellington, acampado, algures entre Hendaia, Saint-Jean-de-Luz e Sain-Jean d' Urube, diante de Baiona. Evidentemente, Fernando VII acei- tou e deixou a prisão dourada de Valençay para tomar as rédeas do seu reino (março de 1814) (MASSIN, 1965). Dois problemas subsistiam, entre muitos outros. Primeiro, a regência recusava ratificar um acordo que havia sido ditado contra vontade (era na realidade plano do imperador, mesmo que ele respondesse às exigências dos Ingleses) e invocando um tratado anteriormente assinado com Londres que proibia negociar uma paz separada. Deusio, as próprias cortes clamavam alto e bom som que só aceitavam o regresso do rei na condição estrita de que ele reconhecesse a Constituição liberal de 1812.

Que importava! No fim do mês de Março de 1814 , Fernando VII tinha passado a fronteira pela Catalunha, libertada como combinado por Suchet - que mantivera a região melhor do que qualquer outro. Como na França, onde desembarcou em Calais o “desejado” Luís XVIII regressado do exílio, a Espanha encontrava também o seu deseado Fernando (PÉREZ, 1996). Este último depois de ter reagrupado as suas forças em Valencia - enquanto Wellington ocupava Toulouse entrou finalmente em Madrid para aí decretar a 4 de maio, com grande pompa, "nula e sem efeito" a Constituição liberal de Cadiz! Doloroso regresso dos Espanhóis à realidade, depois dos sacrifícios da resistência, viam as suas esperanças de transformação (eventualmente progressistas) do país evolar-se nas nuvens de poeira deixadas para trás pelos cavalos dos duques de Albufeira e da Dalmácia. Sabia-se que Fernando era medíocre, mas não mentiroso a este ponto e vil. Mergulhava de novo a Espanha insubmissa no absolutismo. Era preciso vingar, punir, mortificar, fazer expiar. Apesar dos conselhos (mal sussurrados) de clemência dados por Londres, o rei procurou liquidar o que se assemelhava a um revolucionário ou, pior, a um "liberal". Todos os que se rebe- 
laram entre os antigos chefes de guerrilhas, por vezes comandantes de hussardos, outras vezes meio justiceiros meio bandidos, muito populares, iam ser desarmados, presos, deportados. Um dos mais célebres, Juan Martin Diez, El Empecinado (O Invencível), cujas proezas militares se realizaram muito para lá da sua região de origem de Castilla y Leon tinham dado o estatuto de general de brigada (marechal de campo) foi capturado e exibido numa gaiola, em todos os locais públicos de Zamora graças à intervenção dos Cent Fils franceses de Saint-Louis) Depois da noite da ocupação apagaram-se as Luzes em Espanha, onde a torrente da reação levava tudo à frente.

Em 1814, as duas figuras que mais fizeram estremecer o seu respectivo continente, o imperador Napoleão e Simón Bolívar, respectivamente, estavam em declínio. O primeiro, usado, acuado, tinha disposto o que conservava de génio militar perto de Reims para conter os ataques raivosos dos que queriam derrubá-lo, e viu os seus oficiais abandoná-lo na grande maioria - à exceção de Davout, o único a permanecer invencível, e que recuou para Hamburgo, enquanto em toda a parte tudo ruía...O segundo, com algumas centenas de homens e o apoio dificilmente ganho do congresso da Confederação de Nova Granada, tinha conseguido, a partir de Barranco, depois Ocaña, uma série de vitórias importantes, graças a uma audácia fora de comum "que se apoiava no obstáculo para melhor o ultrapassar" como poderia ter dito o célebre Ajacien. Nos primeiros meses de 1813, Cucuta, Merida, Trujillo, umas atrás das outras haviam sido libertadas, e a Guerra à Morte declarada contra a Espanha em junho. A 6 de agosto de 1813, dava-se a entrada triunfal em Caracas, o que o tornou capitão geral dos exércitos e Libertador (outubro). Mas alguns meses mais tarde, concluía-se a Campanha Admirável que the tinha feito percorrer mais de 2 mil quilômetros em menos de um ano. Com ela, terminava a experiência da Segunda Republica. Após a derrota de Puerta (junho de 1814), sob os ataques da "Divisão infernal" os llaneros de José Tomas Boves, era de novo a retirada (julho) (HERRERA TORRES, 2003).

Mas os dois regressariam. Napoleão, para ser aclamado mais uma vez, sobre os caminhos escarpados que levavam a Grenoble, por um campesinato e uma burguesia franceses que não tinham ainda delimitado verdadeiramente os seus interesses de classe e faziam causa comum contra a aristocracia; para sentir uma última vez o gosto da vitória em Ligny (onde, em terra, Bücher, por um curto instante deixou de gritar "Nach Paris!": depois a derrota definitiva. A 15 de junho de 1815, às 21.30, foi o fim de "Bonaparte". Transformado "hóspede" da Inglaterra, seguiu a bordo do Northemberland a 7 de agosto com destino a Santa Helena. Três meses mais tarde, em Paris, alguns dos muitos que haviam traído, inumeráveis, condenavam à morte, e faziam fuzilar o marechal Ney. Instaurava-se a Santa Aliança. E na Espanha de Fernando VII, os exércitos reais finalmente disponíveis podiam ser reenviados para o outro lado do Atlântico. Desde meados de Fevereiro de 1815, uns sessenta navios com mais de 15 mil homens a bordo deixavam a península para as Américas tendo por missão restabelecer a ordem. Era a maior expedição militar dirigida contra as colônias latino-americanas.

A expedição do general Pablo Morillo chegou a Carúpano para esmagar os que falavam de independência ou que manifestassem demasiada simpatia pela democracia. Em abril, o cerco foi posto a Cartagena das Índias, uma das fortalezas da rebelião, que caiu em dezembro. Bogotá e a província de Cundimarca foram retomadas. 
A repressão redobrou de violência, dirigida tanto contra o pequeno povo insurgido como contra os intelectuais e as elites crioulas. Camilo Tenorio, antigo presidente das Províncias unidas de Nova Granada, foi fuzilado em Santa Fé de Bogotá e a sua cabeça exposta como troféu na ponta de uma lança. Um pouco mais tarde, a de José Félix Ribas, que havia enfrentado os ataques espanhóis com um exército de camponeses e estudantes, foi mergulhado em óleo fervente e exposto à população. Diz-se do pacificador Morillo que enviava para o pelotão de execução "todos os indivíduos dos dois sexos que sabiam ler e escrever" (MINGUET; MORVAN, 1983). Mas ele servia habilmente os seus reis: Carlos IV não havia declarado um dia que um americano não tinha necessidade de saber ler e que apenas precisava de temer a Deus e o seu representante, o rei de Espanha? Era já muito tarde. O futuro abria-se com os passos dos Libertadores.

Bolívar tinha ressurgido. O que o próprio general independentista Castillo tinha classificado como "cabeça delirante" à procura de "aventuras quiméricas"; que o general Francisco de Paula Santander, que se tornara adversário político, acusou de desprezar a propriedade privada e de provocar uma guerra interna em que os que nada tinham seriam os vencedores e que são muitos, e os que tinham muito seriam os perdedores, em menor número; que as elites crioulas enriquecidas percebendo que ele podia transformar tudo, e assim o seu domínio social, transformando um movimento de libertação nacional em reformismo radical ou no que poderíamos chamar um "reformismo revolucionário", começavam a odiá-lo totalmente. Aquele a quem os realistas chamavam o "caudilho dos sem camisa" e que a Igreja excomungara, comparando-o a Satanás, a uma "monstruosidade do gênero humano", porque ele afirmara a divór- cio da fidelidade a Cristo e à submissão ao rei de Espanha. Aquele a quem em breve os representantes do governo dos Estados Unidos iriam chamar "o louco da Colômbia", porque libertou os escravos e os colocou com os Índios, ao nível de cidadãos (RODRIGUES).

Simón Bolívar para cúmulo tinha deixado na rota do seu exílio ideias visionárias que feriam todos os candidatos ao despotismo local, expondo o que deveria ser o futuro segundo ele e a união necessária das antigas colônias da América latina que ele sonhava em libertar (manifesto de Cartagena), e unir num só estado, "multinacional" denominado "confederação de nações republicanas" ou a "república das nações" e destinada a impulsionar o desenvolvimento dos povos deste continente e de consolidar a sua soberania diante dos perigos que emanavam de todas as potencias estrangeiras - europeias... e estadunidenses (Carta da Jamaica). No fim do mês de dezembro de 1815 , depois de uma escala a Jacmel para reunir algumas forças e aí receber de Pétion (Papa Bom-Ké), então presidente do estado do Sul do Haiti, dinheiro, armas e barcos - que iria ser decisivo - Bolívar estava de regresso à sua pátria. Como Miranda dez anos antes, teve de voltar lá três vezes para que o desembarque tivesse êxito. Regressado com a mesma tenacidade, o mesmo vigor, mas um sentido político já em fusão com o seu génio militar, conseguiu finalmente reunir um povo e lançá-lo numa epopeia que estava apenas no início. A vitória, a independência, terminaria após mais de um decénio de lutas.

\section{Depois de 1815}

O antigo padre Morelos y Pavon, que havia oferecido aos pobres da Nova Espanha uma parte dos tesouros da Igreja, proibiu o enriquecimento, reuniu mesmo um Congres- 
so americano em Chilpancingo e promulgou a Constituição de Apatzingan, foi vencido por Iturbide (aristocrata crioulo e futuro imperador) e fuzilado em dezembro de 1815, em San Cristobal Ecatepec. Tudo isto aconteceu após a execução de Hidalgo y Costilla, a de Morellos não pôs fim à insurreição, que tornou maciça e teve novos chefes. Um deles, um afro-índio, Vincente Guerrero, que já combatera com Hermenegildo Galeana, fora morto alguns meses antes em Salitral pelos soldados do general realista Calleja. Antes de o país conseguir a independência, muitos outros tiveram de erguer-se e cair; Valério Trujano, morto em combate; Leonardo Bravo, o pai do "Benemérito da Pátria", garroteado; o padre Mariano Matamoros y Guridi, fuzilado; Francisco Javier Mina, espanhol que se tornara um general mexicano, passado pelas armas em Penjamo... Insistimos no fato que, no caso do México, são sobretudo os crioulos que comandavam a repressão. A 9 de julho de 1816, as Províncias unidas do Rio da Prata proclamavam a sua independência e a separação do Paraguai e do Uruguai estavam ratificadas. Simón Bolívar, por si, estava em Barcelona no fim do ano de 1816 e começava a reorganizar os exércitos insurretos com novas ofensivas. Em 1817, aboliu a escravatura em todos os territórios que estavam sob o seu controle. Mas os realistas ainda tinham muitas zonas. À cabeça do exército nos Andes, sem dúvida um dos melhores do continente na época, o general argentino José de San Martin Matorras realizava o prodígio, com os seus soldados e os do chefe da primeira rebelião chilena, Fernando O'Higgins Riquelme, de atravessar os desfiladeiros da Cordilhei- ra dos Andes para dar, após as vitórias do Exercito Libertador em Chacabuco (fevereiro de 1817), depois em Maipu (abril de 1818), a independência do Chile. Em 1818, Simón Bolívar e as forças independentistas de Marino, Bermudez, Arismendi, Valdês, Paez e outros, tinham libertado as regiões da Guiana e do Orenoco, por um lado, as de Barcelona e Cumana, do outro, Iniciou-se a partir de março de 1819, uma tentativa para a libertação da Colômbia, que passou pela travessia dos Andes para retomar Santander, levar com ela a vitória de Boyaca (7 de agosto), entrar em Bogotá (10 de agosto) e declarar a independência da Grande Colômbia, que reunia então os estados atuais da Venezuela, da Colômbia, do Panamá e do Equador (7 de dezembro). Após a ruptura do armistício de 1820, a retomada dos combates em 1821 levava à vitória de Carabobo em Jumjo e à eleição de Bolívar à presidência da Grande Colômbia em setembro. Faltava tomar o último refúgio da presença colonial espanhola, o vice-reinado do Peru, desde a Província de Lima até ao Alto Peru, no mais profundo dos territórios quechua e aymara, onde mais de 20 mil soldados realistas aguardavam o Libertador. A sua marcha lenta para o Sul, uma das mais dolorosas das inumeráveis que realizou, foi, no entanto, cheia de vitórias, principalmente em Bombana, onde acabou por enfrentar forças espanholas e pasturas $^{11}$ reunidas (abril de 1821), ou quando da batalha de Pichincha (maio de 1822), vencida pelo general António José de Sucre y de Alcalá.

Este último juntou-se a Bolívar, entrou em Lima em setembro de 1823, depois da sua travessia dos Andes peruanos e a vitória 
de Junin (agosto de 1824). Finalmente Ayacucho, a 9 de dezembro de 1824, Ayacucho, a última batalha, a que transformou a libertação do Peru na independência de toda a América. Ayacucho, ou a estocada que Sucre e o primeiro exército internacionalista latino-americano deram ao colonialismo espanhol no continente. Sucre, o mais puro, o mais fiel, o mais próximo dos oficiais do Libertador, que foi para ele o que Lannes poderia ter sido para Napoleão - o duque de Montebello, o marechal saído das fileiras, o voluntário engajado do Gers, o único que tratava por tu o imperador e por aquele chorara quando Larrey não conseguiu salvá-lo dos seus ferimentos em Lobau, no Danúbio, depois da batalha de Essling. Sucre e Lannes, talvez os mais bravos, os dois maiores, seguramente os dois mais amados dos seus soldados para sua audácia e a sua humanidade (DAMAMME, 1987). Sucre, que Simón Bolívar achou melhor não aceitar a carga adicional de chefe supremo do novo Estado da Bolívia (a sua filha predileta, para a qual redigiu uma constituição que emancipava as populações ameríndias, largamente maioritárias na região), sugeriu para essa função. E foi ele, o vencedor de Ayacucho, que em 1825 se tornou o primeiro presidente da Bolívia libertada. O próprio Bolívar, já devorado por outras preocupações, problemas de explosão da Grande Colômbia, às decepções do Congresso anfictiónico do Panamá...

Esses combates para a emancipação da América latina, sangrentos, mobilizaram muito menos homens, mas foram iguais em horror aos do velho continente. Demos uma ideia da atrocidade dos métodos de repressão utilizados além-Atlântico pelos es- panhóis. Mas devemos também considerar estas lutas como guerras civis, mais entre autóctones, do que entre espanhóis e latino-americanos. Pois os exércitos espanhóis, ou antes, reais, já englobavam há muito soldados nascidos no ultramar, incluindo ameríndios. Mesmo em Ayacucho, alguns tiveram de enfrentar o exército independentista... Nessa tormenta, havia já várias centenas de veteranos de guerras europeias, tanto militares do império (francês ou não), como soldados das coligações anti-francesas, principalmente britânicos, engajados na Bélgica ou nos Estados Unidos por agentes recrutadores ou redes maçónicas (BRUYÈRE-OSTELLS, 2009). Os inimigos de ontem juntavam-se assim nos regimentos variados de insurrectos da América latina que conquistaram as independências. Os filhos do Novo Mundo conseguiram juntos derrubar a ordem social iníqua única deste outro Antigo Regime que poderia ter sido o império colonial espanhol? Conseguiram obter a unidade continental pela qual Bolívar se lançou de alma e coração? A Justiça social e a união na soberanidade mal se delineiam hoje - e é essa em nossa opinião a actualidade de um Libertador que revive mil existências nos avanços revolucionários de hoje na América latina (HERRERA, 2010).

\section{Abstract}

This article proposes a series of reflections on the links existing between the events which happened from 1795 to 1815 simultaneously in Europe and in this vast space that was then colonial Hispanic America. Over the period con- 
sidered, the two dates that can be seen as turning points are 1807 , or that of the invasion of Spain by the French armies of Napoleon, and 1810, date from which the Hispano-American movements for independence really began.

Key words: History, Europe, Spain, Hispanic America, 1795-1815, Napoleon, Bolívar.

\section{Resumen}

Este artículo propone una serie de reflexiones sobre los eslabones existentes entre los acontecimientos que ocurrieron de 1795 a 1815 simultáneamente en Europa y en el vasto espacio que era entonces la América Hispánica. Durante el período considerado, los dos años que pueden ser vistos como puntos de viraje son 1807, cuando de la invasión de España por los ejércitos franceses de Napoleón, y 1810, cuando los movimientos de independencia hispanoamericanos iniciaron con carácter definitivo.

Palabras clave: América hispánica. Bolívar. España. Europa. Napoleón.

\section{Notas}

1 Ver também sobre o Brasil, cuja história não será aqui abordada directamente: Bastide, Burns (1970), Mauro (1994), Moulier Boutang (1998) e Vignoli, Rego e Marques (2003).

2 Era a linha política do velho William Pitt (conde de Chayham), e de muitos outros.

3 Antes do fim do século XVIII, os Estados Unidos já se tinham virado para Cuba, que se tornou um mercado regional para os seus produtos e a quem compravam açúcar bruto para a sua indústria de refinação da costa leste (em troca de "meios de produção": escravos, material agrícola, viveres, caixas...). E tinham efetuado uma intervenção militar na República Dominicana (1798-1800)... Veja-se aqui: Herrera $(2003,2010)$.

4 Esta lei de limpeza de sangue interditava a ascensão social dos Ameríndios e dos Negros, como a dos Judeus e dos Mouros na Metrópole.

5 Assinalemos que ao contrário da América latina, no Brasil o termo crioulo usa-se para negros.

6 Entre 1864 e 1870, ou seja na altura da Guerra da Tripla Aliança (Brasil, Argentina e Uruguai), muito por baixo, a metade, talvez dois terços, alguns calculam até 9 décimos da parte da população masculina paraguaia foi exterminada. A este respeito ler: Chiavenato (2008).

7 Nas suas Memórias de além túmulo, Chateaubriand revelará na sua opinião que a guerra de Espanha a sua guerra de Espanha, mudou a sua existência e que foi o grande acontecimento político da sua vida...

8 Ler a série de artigos esclarecedores que Marx consagrou a Espanha para o New York Daily Tribune em 1854. E também Marx e Engels.

9 Ler, por exemplo, o que Stendhal conta em A Vida de Napoleão. Consultar o autor deste artigo para debater em pormenor as várias injúrias trocadas (a rainha ganhava).

10 Ler sobre Espanha: Vilar (1990). E sobre a Rússia: Lénine (1974), e também Bettelheim (1974).

11 Forças aliadas aos Espanhóis e compostas de Índios originários da província colombiana de Pasto, que durante muito tempo atrasaram o avanço de Bolivar para o Sul.

\section{Referências}

ARGOTTI CÓRCEGA, Hugo. Ética del Libertador Simón Bolivar segun sus fuentes originales. La Havane: Editorial ce Ciencias Sociales, 2012.

BASTIDE, Roger, Les Amériques noires - Les Civilisations africaines dans le Nouveau Monde, Paris: Payot, 1967.

BAYNTON-WILLIAMS, Ashley; BAYNTONWILLIAMS, Milles. Les Grandes Batailles par les cartes. Paris: Éditions GEO Histoire et Prisma Presse, 2008.

BENOT, Yves. La Démence coloniale sous Napoléon. Paris: La Découverte, 2006. 
BETTELHEIM, Charles. Les Luttes de classes en URSS: 1ère période 1917-1923. Paris: Maspero-Seuil, 1974.

BOHÓRQUEZ, Carmen L. Miranda: Bitácora de un Visionario de Nuesrta América. Caracas: Ediciones de la Presidencia de la Republica, 2008.

BOLIVAR, Simón. Resumen sucinto de la vida del General Sucre. Caracas: Ediciones de la Presidencia de la Republica, 2008.

BRUYÈRE-OSTELLS, Walter. La Grande Armée de la liberté. Paris: Éditions Tallandier, 2009.

BUTEL, Paul, Histoire des Antilles françaises: XVII-XIX siècle. Paris: Perrin, 2002.

CALVO, Thomas. L'Amérique ibérique de 1570 a 1910. Paris: Nathan, 1994.

CASANOVA, Antoine. Napoléon et la pensée de son temps - Une histoire intellectuelle singulière. Ajaccio: Albiana, 2008.

CÉSAIRE, Aimé. Toussaint Louverture - La Révolution française et le problème colonial, (1961). Paris: Présence africaine, 1981.

CHASSAIGNE, Philippe, Histoire de l'Angleterre des origines à nos jours, (1996). Paris: Flamamrion, 2001.

. La Grande-Bretagne et le monde de 1815 à nos jours (1996). Paris: Armand Colin, 2009. CHIAVENATO, Julio. Genocidio Americano: la Guerra del Paraguay. Assunción: Carlos Schauman Editor, 2008.

CHIN, Pat; DUNKEL, Greg; FLOUNDERS, Sara; IVES, Kim Haiti: A Slave Revolution - 200 Years Afrer 1804. New York: International Action Center, 2004.

DAMAMME, Jean-Claude. Lannes Maréchal d'Empire Biographie. Paris: Payot, 1987.

. Les Soldats de la Grande Armée. Paris: Perrin, 1998.

ris: Plon, 2009.
FOUCHÉ, Joseph. Mémoires - Ministre de la Police. Paris: Arléa, 1993.

HERERRA, Rémy. Aspects fondamentaux de l'Histoire de Cuba. In: __ (dir.), Cuba revolutionnaire: Histoire et culture. Paris: L'Harmattan, 2003. p. 11-75.

. Theories of the Capitalist WorldSystem. In: BIDET, J.; KOUVELAKIS, S. (dir). Critical Companion to Contemporary Marxism. Chicago: Haymarket, 2009. p. 209-224.

- Les Avancées révolutionnaires en Amérique latine - Des Transitions socialistes au XXI siècle? Lyon: Parangon, 2010.

HERRERA TORRES, Juvenal. Bolivar y su Campaña Admirable: Lecturas Bolivarianas. Caracas: Ediciones Convivencias de la Corporación Bolivariana Simón Rodriguez, 2003.

JESÚS PÉREZ CRUZ, Felipe. America latina en tiempos de bicentenário. La Havana: Editorial de Ciencias Sociales, 2011.

LAVALLÉ, Bernard. L'Amerique espagnole de Colomb à Bolivar. Paris: Belin, 2004.

LÉNINE, Vladimir I. Le Développement du capitalisme en Russie. Paris: Éditions sociales, 1974.

LENTZ, Thierry. Nouvelle Histoire du Premier Empire: tome II. L'effrondrement du système napoléonien: 1810-1814. Paris: Fayard, 2004.

LÉVY-PROVENÇAL, Évariste. L'espagne musulmane au $X$ siècle: Institutions et vie sociale. Paris: Maisonneuve et Larose, 1932.

MARX, Karl; ENGELS, Friedrich. On Colonialism. Moscou: Progress Publishers, 1959.

MASSIN, Jean. Almanach du Premier Empire: du neuf Thermidor à Waterloo. Paris: Club francês do livro, 1965.

MAURO, Frédéric. Histoire du Brésil. Paris: Editions Chandeigne, 1994.

MELLON, James. Bullwhip Day - The Slaves Remember, an Oral History. New York: Grove Press, Weinfeld \& Nicholson, 1988. 
MINGUET, Charles; MORVAN, Annie. Simon Bolivar - L'Unité impossible, La Découverte. Paris: Maspero, 1983.

MOULIER BOUTANG, Yann. De l'Esclavage au salariat: economie historique du salariat bridé Actuel Marx Confrontaion. Paris: Presses Universiyaires de France, 1998.

PEREIRA, Gustavo. Simón Bolivar - Escritos Anticolonialistas. Caracas: Consejo Nacional de la Cultura, 2005.

PÉREZ, Joseph. Histoire de l'Espagne. Paris. Fayard, 1996.

PORTES, Jacques. Histoire des États-Unis de 1776 à nos jours. Paris: Armand Colins, 2010.

RIBEIRO, Darcy. O Povo Brasileiro: A formação e o sentido do Brasil. São Paulo: Companhia das Letras, 1995.

RODRIGUES, Miguel Urbano. La Campaña Admirable de Bolivar recordada por Juvenal Herrera Torres. Disponível em: <http:/resistencia. columbia.org/index.php/cultura > . Acesso em 23 mar 2017.

RUMAZO González, Alfonso. Francisco de Miranda: Protolider de la independencia Americana. Caracas: Ediciones de la Presidencia de la Republica, 2006.

VIGNOLI, Francisco Humberto; REGO, José Márcio; MARQUES, Rosa Maria. Formação econômica do Brasil. São Paulo: Saraiva Editora, 2003.

VILAR, Pierre. La Guerra Civil Española. La Havane: Editorial de Ciencias Sociales, 1990. 